\title{
Role of Phytochemicals in Perturbation of Redox Homeostasis in Cancer
}

\author{
Shreyas Gaikwad and Sanjay K. Srivastava *(1)
}

Department of Immunotherapeutics and Biotechnology, Center for Tumor Immunology and Targeted Cancer Therapy, Texas Tech University Health Sciences Center, Abilene, TX 79601, USA; shreyas.gaikwad@ttuhsc.edu

* Correspondence: sanjay.srivastava@ttuhsc.edu; Tel.: +1-325-696-0464; Fax: +1-325-696-3875

check for

updates

Citation: Gaikwad, S.; Srivastava,

S.K. Role of Phytochemicals in

Perturbation of Redox Homeostasis in Cancer. Antioxidants 2021, 10, 83 https://doi.org/10.3390/antiox100 10083

Received: 25 November 2020

Accepted: 5 January 2021

Published: 9 January 2021

Publisher's Note: MDPI stays neutral with regard to jurisdictional clai$\mathrm{ms}$ in published maps and institutional affiliations.

Copyright: $(\odot 2021$ by the authors. Licensee MDPI, Basel, Switzerland. This article is an open access article distributed under the terms and conditions of the Creative Commons Attribution (CC BY) license (https:// creativecommons.org/licenses/by/ $4.0 /)$.

\begin{abstract}
Over the past few decades, research on reactive oxygen species (ROS) has revealed their critical role in the initiation and progression of cancer by virtue of various transcription factors. At certain threshold values, ROS act as signaling molecules leading to activation of oncogenic pathways. However, if perturbated beyond the threshold values, ROS act in an anti-tumor manner leading to cellular death. ROS mediate cellular death through various programmed cell death (PCD) approaches such as apoptosis, autophagy, ferroptosis, etc. Thus, external stimulation of ROS beyond a threshold is considered a promising therapeutic strategy. Phytochemicals have been widely regarded as favorable therapeutic options in many diseased conditions. Over the past few decades, mechanistic studies on phytochemicals have revealed their effect on ROS homeostasis in cancer. Considering their favorable side effect profile, phytochemicals remain attractive treatment options in cancer. Herein, we review some of the most recent studies performed using phytochemicals and, we further delve into the mechanism of action enacted by individual phytochemicals for PCD in cancer.
\end{abstract}

Keywords: oxidative stress; cancer; reactive oxygen species (ROS); phytochemicals; dietary chemicals; natural compounds; programmed cell death; apoptosis; anoikis; autophagy; ferroptosis; pyroptosis

\section{Introduction \\ 1.1. ROS and Its Physiological Role}

Reactive oxygen species (ROS) is a blanket term which encompasses several reactive species derived from molecular oxygen [1]. ROS are short-lived highly reactive byproducts of aerobic metabolism. They are formed due to single-electron reduction of oxygen $\left(\mathrm{O}_{2}\right)$ which forms radical superoxide $\left(\mathrm{O}_{2}{ }^{\bullet-}\right)$. The superoxide molecules are then converted to hydrogen peroxide $\left(\mathrm{H}_{2} \mathrm{O}_{2}\right)$ in the presence of superoxide dismutase [2]. Reactions involving $\mathrm{H}_{2} \mathrm{O}_{2}$ and $\mathrm{O}_{2}{ }^{-}$result in further generation of other ROS molecules such as hydroxyl radicals $(\mathrm{OH})$, singlet oxygen $\left({ }^{1} \mathrm{O}_{2}\right)$, and peroxynitrite $\left(\mathrm{ONOO}^{-}\right)$[3]. Mitochondria is the biggest source of ROS where $80 \%$ of the ROS are generated. Once generated, ROS oxidize several cellular molecules and hence play diverse roles in various physiological processes of the cells [4]. ROS react with carbohydrates, lipids, proteins, and nucleic acids, resulting in functional alterations of pathways associated with cellular differentiation, proliferation, cytoskeletal regulation, and apoptosis [3,5]. Several protein structures such as ion channels, kinases, phosphatases are regulated by redox signaling $[5,6]$. In signal transduction, ROS transiently oxidizes the cysteine sulfhydryl group which is involved in the activation of most phosphatases [7]. ROS have been considered as a harmful by-product of aerobic metabolism, however, under balanced conditions, ROS play an important role as mediators of signaling pathways in various physiological systems [8]. The biological activity of ROS depends on the extent, location, and duration of action of the specific ROS molecule [9]. For example, in embryonic development, optimum levels of $\mathrm{H}_{2} \mathrm{O}_{2}$ are considered to be crucial for neuronal growth. A level of 1-10 $\mathrm{nM} \mathrm{H}_{2} \mathrm{O}_{2}$ is required for neuronal growth as levels below $1 \mathrm{nM}$ have shown spatial memory defects in mice studies, while levels above $10 \mathrm{nM}$ result in axonal degeneration $[10,11]$ In the cardiovascular system, 
mitochondrial ROS (mROS) are suggested to be involved in the dilation of human coronary resistance arteries in response to shear stress [12]. Additionally, in terms of optimal vascular angiogenesis, NADPH oxidase (NOX) is activated by vascular endothelial growth factor (VEGF) to produce ROS. The produced ROS and VEGF together then induce endothelial cell proliferation and migration [13]. For optimal blood vessel growth, a specific range of ROS called the "redox window" is required [14]. ROS have been observed to be involved in cognitive functioning wherein it was determined that mROS potentiates post-synaptic inhibitory signaling in cerebellar stellate cells via selective recruitment of $\alpha 3$-containing GABAA receptors [15]. Host-defense against pathogens was the first function of ROS to be discovered. Hypochlorous acid $(\mathrm{HOCl})$ produced from chlorine and $\mathrm{H}_{2} \mathrm{O}_{2}$ generates chloramines which have cytotoxic effects [16]. In terms of host defense mechanism, after phagocytosis of the pathogen, NADPH oxidase (NOX) produces a high amount of ROS which in turn destructs the pathogen [17]. In the immune system, ROS coordinate the migration of polymorphonuclear leukocytes (PMNs) towards the pathogens, and then ROS also retain the PMNs at the site of infection [18]. T cell activation and proliferation are mediated through a signaling cascade mainly involving the MAPK/ERK pathway [19]. Protein tyrosine phosphatases (PTPs) negatively regulate the MAPK/ERK pathway and PTPs have a cysteine (Cys) residue in their active site which is regulated by ROS. ROS act as inhibitor of PTP by converting Cys residue in the active site to sulfenic acid (Cys-SOH), thus leading to activation of the MAPK/ERK pathway [20]. To summarize, ROS serve as important mediators in several physiological systems and the level of ROS molecules play a key role in its action.

\subsection{Oxidative Stress in Cancer}

A constant balance of ROS levels is required for appropriate homeostasis. Under normal conditions, our body's antioxidant defense system continuously counteracts the oxidative attack from ROS molecules [21]. However, excessive accumulation of ROS within the cell disrupts the balance, leading to the generation of oxidative stress [22,23]. The generated oxidative stress leads to irreversible damage of DNA, peroxidation of lipids, oxidation of proteins, and inhibition of enzymes [1]. A high level of ROS present in oxidative stress conditions leads to the activation of various oncogenic pathways [6]. The phosphoinositide 3-kinases (PI3K) pathway is highly activated in a number of cancers. ROS primarily inactivate phosphatase and tensin homolog (PTEN) in the PI3K pathway by oxidizing Cys124, an active site on PTEN, leading to a disulfide bond with another intraprotein Cys71. Consequently, the inactivation of PTEN leads to hyper-activation of the PI3K pathway [24]. Constant phosphorylation of PI3K subsequently results in the activation of protein kinase B (AKT) via downstream pyruvate dehydrogenase kinase 1 (PDK1), ultimately leading to the upregulation of cell cycle stimulating genes such as proliferating cell nuclear antigen (PCNA) and cyclin-dependent kinase 1 (CDK1) [25]. In many Kirsten rat sarcoma viral oncogene homolog (KRAS) mutated oncogenic cancers, ROS play an important role in anchorage-independent growth through regulation of the ERK MAPK signaling pathway [26]. In the initial stage of tumor formation, angiogenesis is absent or poorly developed, resulting in hypoxic conditions. The hypoxic condition affects the mitochondrial electron transport chain (ETC), leading to increased ROS levels. Hypoxia-driven ROS play a role in the activation of hypoxia inducing factor-1 (HIF-1), a transcription factor that contributes towards glucose to lactate conversion for tumor glucose metabolism and the induction of VEGF. ROS activate the HIF-1 subunit by inactivating a HIF-1 inhibitor, PHD (prolyl dydroxylase domain) [27]. Increased ROS levels have been linked to tumor proliferation via the c-Myc pathway. At increased ROS levels, HIF$1 \alpha$ dependent activation of c-Myc occurs, resulting in tumor proliferation and DNA damage [28]. ROS also play a role in tumor stromal environment and activate invasive tumor progression. Increased ROS levels in stromal fibroblasts by transforming growth factor beta-1 (TGFß1) initiated the mesenchymal-mesenchymal transition (MMT) and secretion of vascular endothelial growth factor (VEGF), hepatocyte growth factor (HGF), 
and interleukin-6 which are biomarkers for invasive tumor cells [29]. ROS affect the matrix metalloproteinase (MMP)/tissue inhibitor of metalloproteinase (TIMPs) ratio by activating MMP synthesis. ROS activate MMP synthesis either via Ras and MAPK signaling cascades or through NFKB pathway [30]. Cancer cells survive on levels of ROS that are slightly greater than normal cell counterparts and activate various oncogenic pathways. The cells adapt themselves to the moderate redox environment and proliferate. However, if ROS levels rise beyond a certain threshold, the transformed cancer cells are longer able to adapt and turn to various cell death pathways [31].

\section{ROS and Associated Programmed Cell Death (PCD) Pathways}

\subsection{Apoptosis}

Among all the PCD pathways, apoptosis is the most studied pathway which is mediated via a group of proteins called cysteine-dependent aspartate-directed proteases known as caspases [32]. ROS play a role in both extrinsic and intrinsic apoptosis pathways. The intrinsic pathway is mediated through the mitochondrial permeability transition pore (mPTP). ROS cause cytoplasmic release of cytochrome c from the mitochondria via its action on PTP. Specifically, ROS govern the regulation of three proteins adenine nucleotide translocase (ANT), cyclophilin D, and voltage-dependent anion-selective channel (VDAC) involved in the opening of PTP. ROS oxidizes specific cysteines in their active sites $[33,34]$. The intrinsic pathway is a more common apoptosis mode mediated by ROS since mitochondria is very sensitive to the increased ROS levels as it lacks DNA repair enzymes. In hyperactivated oxidative stress, the shutdown of mitochondrial function contributes to apoptosis as cellular energy supply stops [35,36]. In the extrinsic pathway also known as the death receptor pathway, TNF receptors are involved which are located at the plasma membrane and contain an intracellular death domain. These receptors recruit pro-caspases and adaptor proteins, which results in the formation of death-inducing signaling complex (DISC) and activates the caspases [37]. In this process, the cellular FLICE-inhibitory protein (c-FLIP) impedes the formation of DISC [38]. ROS mediate the downregulation of FLIP by ubiquitination and subsequent degradation by the proteasome. Primarily, $\mathrm{H}_{2} \mathrm{O}_{2}$ and $\mathrm{O}_{2}{ }^{\bullet-}$ are responsible for FLIP down-regulation [39].

\subsection{Autophagy}

Autophagy is a catabolic process required for the regeneration of damaged organelles and cellular components under various stressful environments such as pathogen infection, growth factor deprivation, starvation, and intra-cellular stress [40]. Autophagy involves the generation of a double-membrane vesicle, called autophagosome, which engulfs the damaged components and merges with lysosome for hydrolytic degradation of the engulfed cargo [41,42]. A definite interplay exists between ROS and autophagy since both are induced by common oncogenic stimuli [43]. Under normal conditions, autophagy mediates cell survival by eliminating ROS and protecting the mitochondria. However, when stimulated, ROS induce excess autophagy resulting in cell death [44]. ROS regulates a negative regulator of autophagy, the mammalian target of rapamycin complex 1 (mTORC1). Inhibition of mTORC1 is mediated through cytoplasmic ataxia telangiectasia mutated (ATM). ATM activates the tuberous sclerosis complex 2 (TSC2) tumor suppressor which inhibits mTOR via stimulation of GTP hydrolysis of Ras family small GTPase Rheb (Ras homolog enriched in brain) [45,46]. Additionally, oxidative stress activates FOXO3 which stimulates the transcription of $\mathrm{Bcl}-2$ nineteen kilodalton interacting protein (BNIP3) [47]. BNIP3 in turn competes with Beclin-1 for binding to Bcl-2. The unbound Beclin1 induce autophagic cell death [48]. However, autophagy acts in a context dependent manner and might play a pro-tumor role in certain conditions [49].

\subsection{Ferroptosis}

Ferroptosis, a novel form of programmed cell death, is characterized by the accumulation of iron and lipid peroxidation, leading to intracellular changes such as changes in 
mitochondrial structure and functioning [50]. The mechanism involved in ferroptosis is the suppression of system $X_{c}$, an amino acid antitransporter. System $X_{c}$ is a part of an important antioxidant system in cells that provokes the synthesis of glutathione (GSH). GSH decreases ROS levels under the action of glutathione peroxidases (GPXs), thereby maintain a balanced oxidant-antioxidant environment. During ferroptosis, inhibiting system $\mathrm{X}_{\mathrm{C}}$ causes decreased synthesis of GSH, leading to the accumulation of lipid ROS and ultimately, oxidative cell death [51]. Among GPXs, GPX4 is a pivotal player that counterbalances lipid peroxides and protects membrane integrity by using GSH as a cofactor [52]. In terms of cancer therapy, GPX4 is targeted as it is a specific and central regulator of ferroptotic cell death [53].

\subsection{Pyroptosis}

Pyroptosis is a caspase-dependent (caspase 1/4/5/11) mode of cell death, which is initiated by the formation of the inflammasome. The mechanism involves caspasemediated cleavage of gasdermin D (GSDMD) and gasdermin E (GSDME). Following the cleavage, the N-terminal fragment of GSDMD is released and it forms pores in the cell membrane, leading to activation of inactive cytokines like IL-18 and IL-1 $\beta$, water influx, cell swelling, and osmotic lysis [54]. ROS induce pyroptosis through the activation of NLR family pyrin domain containing 3 (NLRP3) inflammasome [55].

\subsection{Anoikis}

Anoikis is another apoptotic PCD wherein cells undergo death in the absence or improper attachment to the extracellular matrix (ECM). Anoikis is a Greek term for "homelessness" [56-58]. In cancer cells, the sonic hedgehog/Gli1 pathway is a well-known regulator of anoikis $[59,60]$. Additionally, ROS has been implicated to support anoikis resistance, however, depending upon the activation, ROS trigger anoikis-inducing cell death [61].

\section{Phytochemicals: A Promising Role in ROS Mediated Cancer Cell Death}

Considering the plethora of evidence generated from various studies, it is clear that beyond a threshold value, ROS play an anti-tumorigenic role. Therapeutic interventions to achieve the required threshold ROS level is a promising strategy for inducing PCD. Phytochemicals are naturally occurring compounds derived from plants and have been studied for their therapeutic effects in various physiological conditions. Multiple phytochemicals have proven their inheritance of cancer prevention and therapeutic properties $[62,63]$. The low side-effect profile of phytochemicals has made them a prominent arsenal against cancer. These naturally derived compounds are a valuable resource for cancer treatment and we hereupon discuss some of the phytochemicals studied in ROS-mediated anti-cancer activity.

\subsection{Phytochemicals Acting via ROS-Mediated Apoptosis}

\subsubsection{Capsaicin}

Capsaicin ( $N$-vanillyl-8-methylnonenamide) is a homovanillic acid derivative obtained from hot chili pepper [64]. Capsaicin has been widely studied for its anti-cancer activity $[65,66]$. Its activity is proposed to be mediated through oxidative stress-induced apoptosis. In pancreatic cancer cell lines BXPC-3 and AsPC-1, 4 to 6-fold ROS generation was observed within $1 \mathrm{~h}$ of capsaicin treatment while ROS generation was absent in normal pancreatic cells. Capsaicin induced oxidation of cardiolipin, a component of mitochondria. Oxidation of cardiolipin subsequently led to apoptosis. ETC complex-I and complex-III were observed to be the ROS-producing entities following capsaicin treatment $[67,68]$.

\subsubsection{Sulforaphane}

Sulforaphane (SFN; 1-isothiocyanato-4-(methyl-sulfinyl)-butane) is an isothiocyanate present in cruciferous vegetables like cabbage, broccoli, cauliflower, and kale [69]. Sulforaphane induced ROS mediated apoptosis in PC-3 and DU145 human prostate cancer 
cells. Specifically, caspase-8 activation and Fas protein induction following sulforaphane treatment confirmed apoptotic activity. ROS generation was suggested to be caused by both nonmitochondrial and mitochondrial mechanisms. GSH depletion was proposed to be the non-mitochondrial mechanism. ROS were postulated to be upstream activators of apoptosis based on caspase-8 attenuation following treatment with EUK-134 (SOD and catalase mimetic) [70].

\subsection{3. $\alpha$-Lipoic Acid}

$\alpha$-lipoic acid (1,2-Dithiolan-3-yl pentanoic acid) is a naturally occurring dithiol compound found in fruits and vegetables [71]. In hepatocellular carcinoma cell line HepG2, it induced mitochondrial apoptosis preceded by ROS generation. Precisely, $\alpha$-lipoic acidinduced ER (endoplasmic reticulum) stress wherein increased levels of C/EBP homologous protein (CHOP) were detected. ER stress led to activation of PERK (phospho- extracellular signal-related kinase) pathway and IRE1 (inositol-requiring enzyme 1) pathway leading to apoptosis. $\alpha$-lipoic acid also inhibited ATF6 (activating transcription factor 6)-mediated pro-survival pathway [72].

\subsubsection{Benzyl Isothiocyanate (BITC)}

BITC is an isothiocyanate present in cruciferous vegetables such as cauliflower, mustard, watercress, cabbage, and horseradish [73]. BITC has been studied for its anti-cancer effects in various studies previously [74-78]. BITC was studied for its anti-cancer potential in pancreatic cancer cell lines Capan-2 and MIAPaCa-2 cells. BITC treatment activated MAPK signaling with activation of ERK and JNK observed within as early as $1 \mathrm{~h}$ of treatment while ROS generation was observed within 30 min of treatment. Additionally, activation of MAPK family members was absent in normal HPDE-6 cell line. Thus, BITC treatment led to ROS generation followed by activation of MAPK family members ERK, JNK, and P38 and subsequently apoptosis [79].

\subsubsection{Phenethyl Isothiocyanate (PEITC)}

PEITC, another isothiocyanate present in cruciferous vegetables has been studied for its anti-cancer effects and ROS-generating properties [80-85]. In a study to investigate effects of PEITC on breast cancer cells, PEITC showed ROS-mediated apoptosis in MDAMB-231 and MCF-7 cell lines. High levels of hydrogen peroxide were observed in the cancer cells following treatment with PEITC. An antioxidant pre-treatment blocked cellular death and percent apoptosis induced by PEITC. Thus, confirming high levels of ROS led to apoptotic cell death [86].

\subsubsection{Piperine}

Piperine [1-(5-[1,3-benzodioxol-5-yl]-1-oxo-2,4-pentadienyl) piperidine] is an alkaloid extracted from black pepper (P. nigrum) and long pepper (P. longum) [87]. Various small molecules derived from the Piperaceae family have been implicated in ROS-mediated apoptotic cell death of cancer cells [88,89]. Piperine has been implicated for ROS generation in SKMEL-28 and B16-F0 melanoma cell lines. ROS generation was observed within $30 \mathrm{~min}$ of treatment and the levels sustained until $24 \mathrm{~h}$. Phosphorylation of Chk1 (checkpoint kinase 1) was observed in response to DNA damage which consequently led to G1 cell cycle arrest and apoptosis. Significant expression of phosphorylated ataxia telangiectasia and Rad3 related protein (ATR) at Ser 428 and Chk1 at Ser 296 was observed, suggesting DNA damage [90].

\subsubsection{Curcumin}

Curcumin (1,7-bis(4-hydroxy-3-methoxyphenyl)-1,6-heptadiene-3,5-dione) is a polyphenol derived from rhizome of Curcuma longa. It possesses pleiotropic therapeutic benefits including anti-cancer effects [91,92]. The apoptotic role of curcumin was studied in colorectal cancer and sequential dosing was considered important for ROS-mediated apoptotic 
induction. In the study, the sequential treatment caused lysosomal permeabilization and ROS generation, accompanied by autophagic dysregulation and ER stress. Lysosomal permeabilization resulted in BID-dependent mitochondrial membrane permeabilization and thereby caspase-dependent apoptosis. Cathepsin B was confirmed to be involved in apoptosis following sequential treatment [93]. Figure 1 depicts the ROS-mediated apoptotic action of phytochemicals.

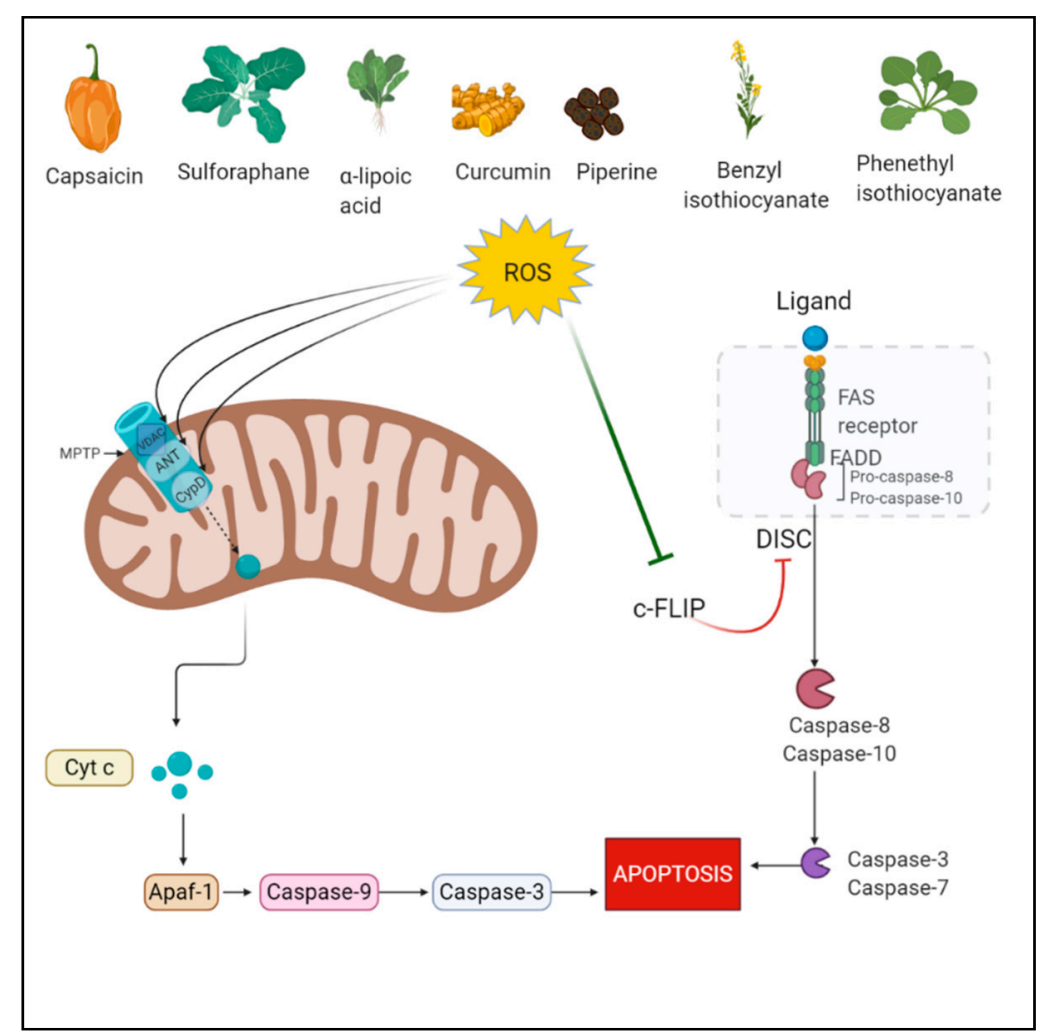

Figure 1. Reactive Oxygen Species (ROS)-mediated apoptotic action of phytochemicals. Figure created with BioRender.com.

\subsection{Phytochemicals Acting via ROS-Mediated Ferroptosis}

\subsubsection{Withaferin A}

Withaferin A (WA) is a steroidal lactone isolated from the plant Withania somnifera. It has been widely studied for anti-inflammatory and anti-tumorigenic properties [94]. Withaferin A induced ferroptotic cell death in neuroblastoma cells. WA targeted Keap-1 (kelch-like ECH-associated protein (1), a negative regulator of Nrf2 (nuclear factor erythroid 2-related factor (2). Keap-1 inhibition caused the release of Nrf2. The released Nrf2 upregulated HMOX1 [heme oxygenase (decycling) 1] which catalyzes heme degradation to generate ferrous iron $\left(\mathrm{Fe}^{2+}\right)$. A high concentration of $\mathrm{Fe}^{2+}$ led to ROS generation and ultimately cellular death [95].

\subsubsection{Bromelain}

Bromelain is a mixture of proteolytic enzymes derived from the stem of pineapple plants belonging to the Bromeliaceae family [96]. Bromelain was shown to induce ferroptotic cell death in KRAS-mutant colorectal cancer wherein bromelain increased the level of longchain acyl-CoA synthetase-4 (ACSL4) an isozyme which plays role in lipid biosynthesis and fatty acid degradation. Specifically, ACSL4 accumulates oxidized cellular membrane phosphoplipids. ACSL4 mainly acts on phosphatidylethanolamine levels which act as an executioner of ferroptotic cell death $[81,97]$. 


\subsubsection{Ruscogenin}

Ruscogenin [(1 $\beta, 3 \beta, 25 R)$-Spirost-5-ene-1,3-diol] is a steroidal sapogenin extracted from Ruscus aculeatus plant [98]. Ruscogenin was studied for ferroptotic effects in pancreatic cancer cell lines BxPC-3, SW1990, PANC-1, and AsPC-1. Ruscogenin treatment increased $\mathrm{Fe}^{2+}$ ion concentration by upregulating the expression of transferrin and downregulating the expression of ferroportin. To further confirm the mode of action, cell death by ruscogenin reduced following treatment with iron chelator and cell death increased when ferric ammonium citrate was added. To conclude, ruscogenin regulated iron transport resulted in overproduction of ROS, leading to cell death [99].

\subsubsection{Oridonin}

Oridonin (Ori) is a tetracyclic diterpenoid obtained from Isodon Rubescens [100]. The ferroptotic effect of Ori was studied in esophageal cancer cell line TE1 and inhibition of the gamma-glutamyl cycle was observed in oridonin treated cells. Precisely, Ori affected GGT1, a key enzyme in the gamma-glutamyl cycle, which is crucial for protecting cells from oxidative stress and maintaining cysteine homeostasis. Additionally, Ori inhibited GSH by a covalently binding with cysteine after entering the TE1 cells. The covalent binding reduces intracellular cysteine levels which is responsible for ferroptosis. A decrease in GPX4 level was also detected after Ori treatment [101,102]. Figure 2 depicts the ROS-mediated ferroptotic action of phytochemicals.

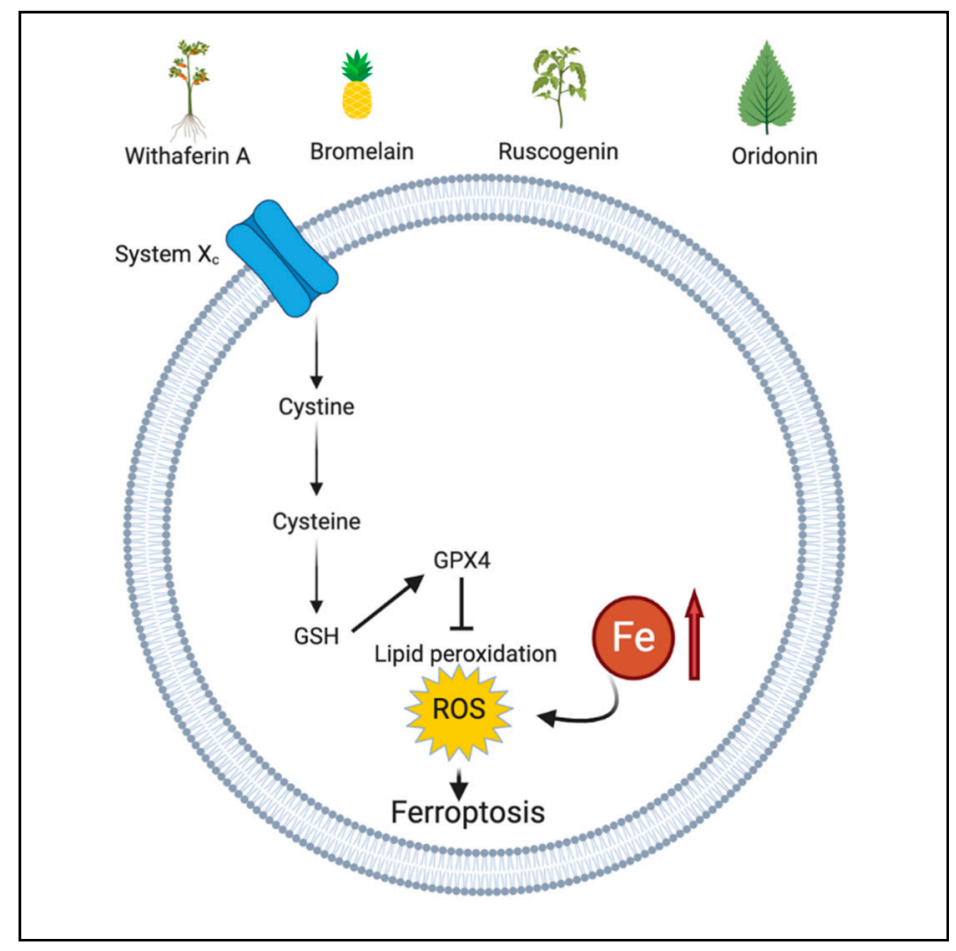

Figure 2. ROS-mediated ferroptotic action of phytochemicals. Figure created with BioRender.com.

\subsection{Phytochemicals Acting via ROS-Mediated Autophagy}

\subsubsection{Cucurbitacin B}

Cucurbitacin B (1,2-Dihydro-alpha-elaterin) is a tetracyclic triterpene compound found in the plants of Cucurbitaceae and other also a variety of other plant families. Some of the sources of cucurbitacin B are Helicteres angustifolia, Licaniaintra petiolaris, Casearia arborea, and Cucumis prophetarum [103]. Cucurbitacin B has been studied for its anticancer effects in human cervical cancer HeLa cells. Cucurbitacin B induced autophagic cell death and was observed to have mediated through mitochondrial ROS production. Treatment of HeLa cells with cucurbitacin-B resulted in accumulation of several lamellar structures having 
cytosolic autophagic vacuoles. Additionally, the conversion of non-autophagic soluble LC3 (LC3-I) to autophagic LC3 (LC3-II) was detected following treatment with cucurbitacin-B. Pretreatment with antioxidant NAC and Mito-TEMPO (mitochondria-targeting antioxidant) inhibited LC3-II conversion, cell death, and autophagosome formation. Thus, the results indicated that ROS plays an important role in promoting autophagic cell death following cucurbitacin treatment [104]. Another study confirmed cucurbitacin-B induced autophagic cell death via ROS in MCF-7 breast cancer cells. The role of ROS was confirmed by the use of antioxidant pretreatment which reduced protein expression of LC3 II [105].

\subsubsection{Silibinin}

Silibinin is a flavonoid derived from the milk thistle plant (Silybum marianum). The autophagic activity of silibinin was studied in human fibro-sarcoma HT1080 cells wherein silibinin was shown to activate p53 via the ROS-p38 pathway. Activation of p53 partially mediated autophagic cell death by inhibiting the MEK/ERK1/2 and PI3K/Akt pathway. An increased expression of Beclin1 (autophagosome marker) and conversion of LC3 I to LC3 II was observed following silibinin treatment [106]. Another study indicated that silibinin induces autophagic cell death mediated through mitochondrial dysfunction [107].

\subsubsection{Allicin}

Allicin (2-propene-1-sulfinothioic acid S-2-propenyl ester) is an organosulfur compound present in garlic initially studied for its anti-bacterial studies [108]. Allicin was shown to induce both autophagy and apoptosis via increased production of ROS in nonsmall cell lung cancer cell lines A549 (adenocarcinoma) and NCI-H460 (large cell carcinoma). The authors observed a dose-dependent autophagic action of allicin. At low doses, allicin induced autophagy associated with moderate ROS levels, while increased doses resulted in higher ROS production and lysosomal disruption leading to cell death. The lysosomal disruption resulted in intra-cellular hydrolytic enzyme release [109]. Similar autophagic action of allicin was studied in hepatocellular carcinoma cells. Interestingly, allicin caused autophagy induction in p53 normal human liver cancer cells while apoptosis in p53 deficient cell line showing the dependence of its autophagic action on p53 [110].

\subsubsection{Carnosol}

Carnosol is an ortho-diphenolic diterpene found in Mediterranean herbs rosemary, sage, and oregano [111]. Although it has been studied for its antioxidant activity, some evidence also shows the cytotoxic effects of carnosol via ROS overproduction. ROS production by carnosol is a dose and time-dependent process [112]. Carnosol study in MDA-MB 231 breast cancer cells showed ROS accumulation within $1 \mathrm{~h}$ of treatment while LC3II accumulation at $3 \mathrm{~h}$ post-treatment, suggesting ROS to be an upstream inducer of autophagy. It was observed that at lower concentration $(<25 \mu \mathrm{M})$, carnosol-induced ROS-mediated autophagy only, while at higher concentration $(>50 \mu \mathrm{M})$, ROS induced both autophagy as well as apoptosis. Interestingly, autophagy induction by carnosol was beclin-1 independent [113].

\subsubsection{Quercetin}

Quercetin is a flavonoid found in fruits such as grapes, red raspberry, apples, and vegetables like broccoli, shallots, tomatoes, onion, and tea [114]. Quercetin has been widely studied for its anti-cancer effects and exerts its effects through multiple pathways. A study of quercetin in osteosarcoma cells revealed it activates autophagic flux via its action on nuclear protein 1 (NUPR1) which is involved in autophagosome formation, cargo degradation, and autophagosome-lysosome fusion. It was observed that quercetin-induced overproduction of ROS led to increased expression and activation of NUPR1. Although a majority of the studies show an inverse relation between NUPR1 and ROS, a direct relation is hypothesized $[115,116]$. 


\subsubsection{Berberine}

Berberine (5,6-dihydro-9,10-dimethoxybenzo[g]-1,3-benzodioxolo[5,6-a] quinolizinium) is a quaternary benzylisoquinoline alkaloid derived from stem bark and roots of many plants and mainly the plants belonging to genus Berberis [117]. Recently, berberine was investigated for its anticancer role in the renal cell carcinoma model wherein it was combined with photodynamic therapy (PDT). The fluorescent nature of berberine was a key characteristic of the combinational effect. Berberine was used as a photosensitizer agent because the complementary action of a photosensitizer agent with a laser induces ROS generation, leading to cellular death. Berberine along with PDT showed significantly increased autophagy in comparison to berberine alone, suggesting photoactivation of berberine is required for ROS-mediated autophagy and ultimate cell death [118]. Figure 3 depicts the ROS-mediated autophagic action of phytochemicals.

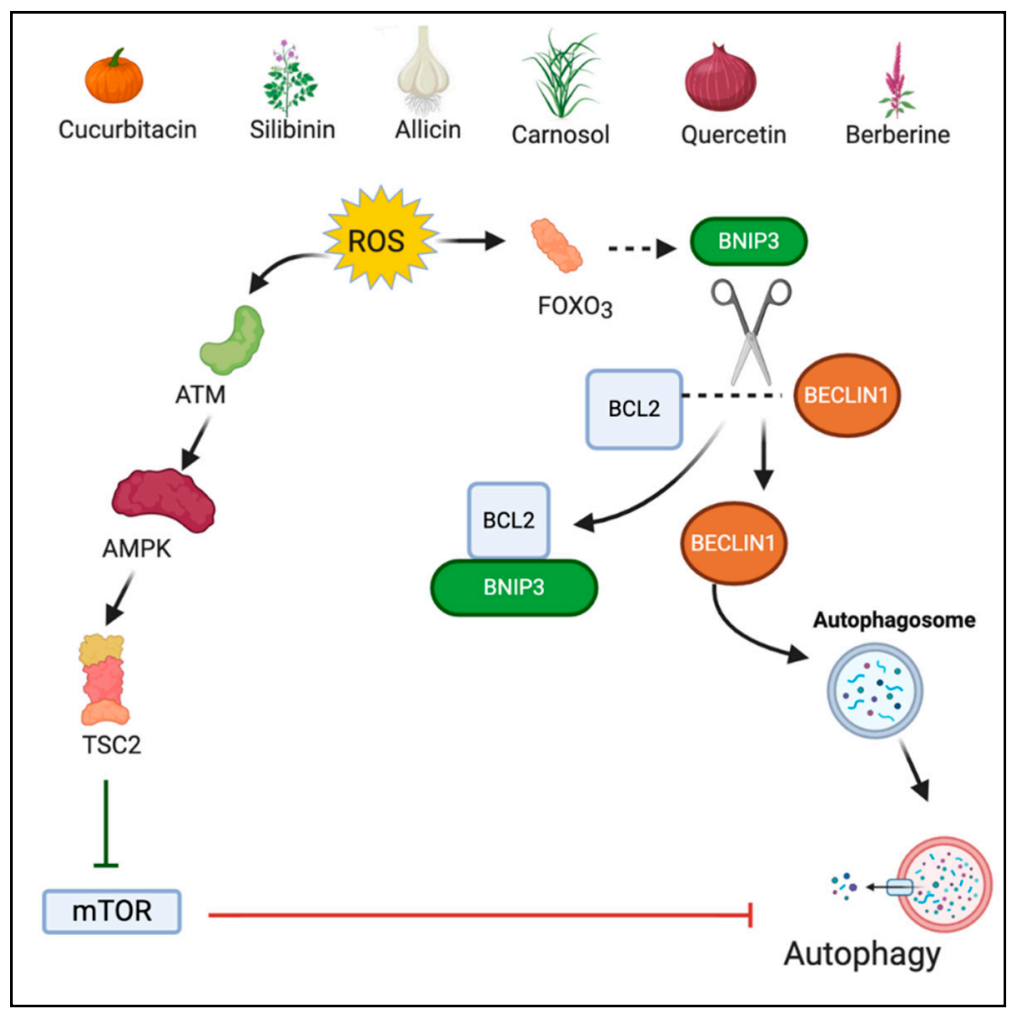

Figure 3. ROS-mediated autophagic action of phytochemicals. Figure created with BioRender.com.

\subsection{Phytochemicals Acting via ROS-Mediated Pyroptosis \\ Nobiletin}

Nobiletin $\left(5,6,7,8,3^{\prime}, 4^{\prime}\right.$-hexamethoxyflavone) is a polymethoxyflavonoid extracted from citrus fruits. Nobiletin has various pharmacological activities such as antimetabolic disorder, anticancer, neuroprotection, anti-inflammation, antioxidation, and cardiovascular protection [119]. Nobiletin was studied for its anti-cancer activity in human ovarian carcinoma cell lines A2780 and OVCAR3. In the study, nobiletin treatment resulted in ROS generation, exhibited by a significant decrease in mitochondrial membrane potential in a dose-dependent manner. Further, ROS contributed to the cleavage of GSDMD and GSDME, the two biomarkers of pyroptosis among which GSDMD is considered to be an executioner of pyroptosis $[120,121]$. Figure 4 depicts the ROS-mediated pyroptotic action of phytochemicals. 


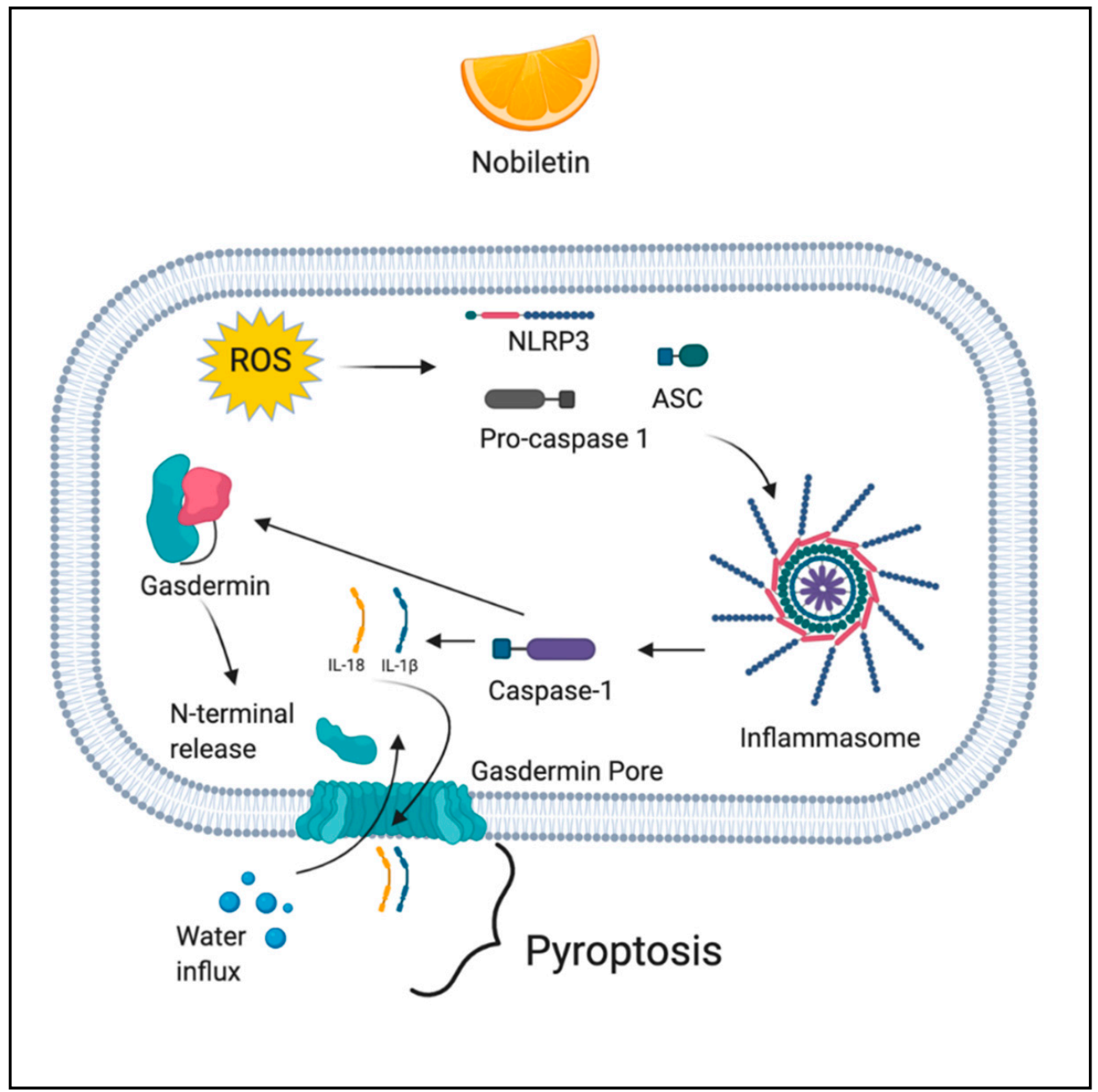

Figure 4. ROS-mediated pyroptotic action of phytochemicals. Figure created with BioRender.com.

\subsection{Phytochemicals Acting via ROS-Mediated Anoikis}

Emodin

Emodin (1,3,8-trihydroxy-6-methylanthraquinone) is an anthraquinone derivative obtained from rhubarb plant (Rheum palmatum) and Aloe vera [122]. Emodin was shown to induce ROS generation followed by anoikis in gastric cancer cells. Emodin induced oxidative stress and caused inactivation of RhoA, a crucial signaling molecule in the cytoskeletal rearrangement. Inactivation of RhoA led to the disruption of focal adhesion complex and ultimately anoikis [61]. Figure 5 depicts the ROS-mediated anoikis by phytochemicals. 


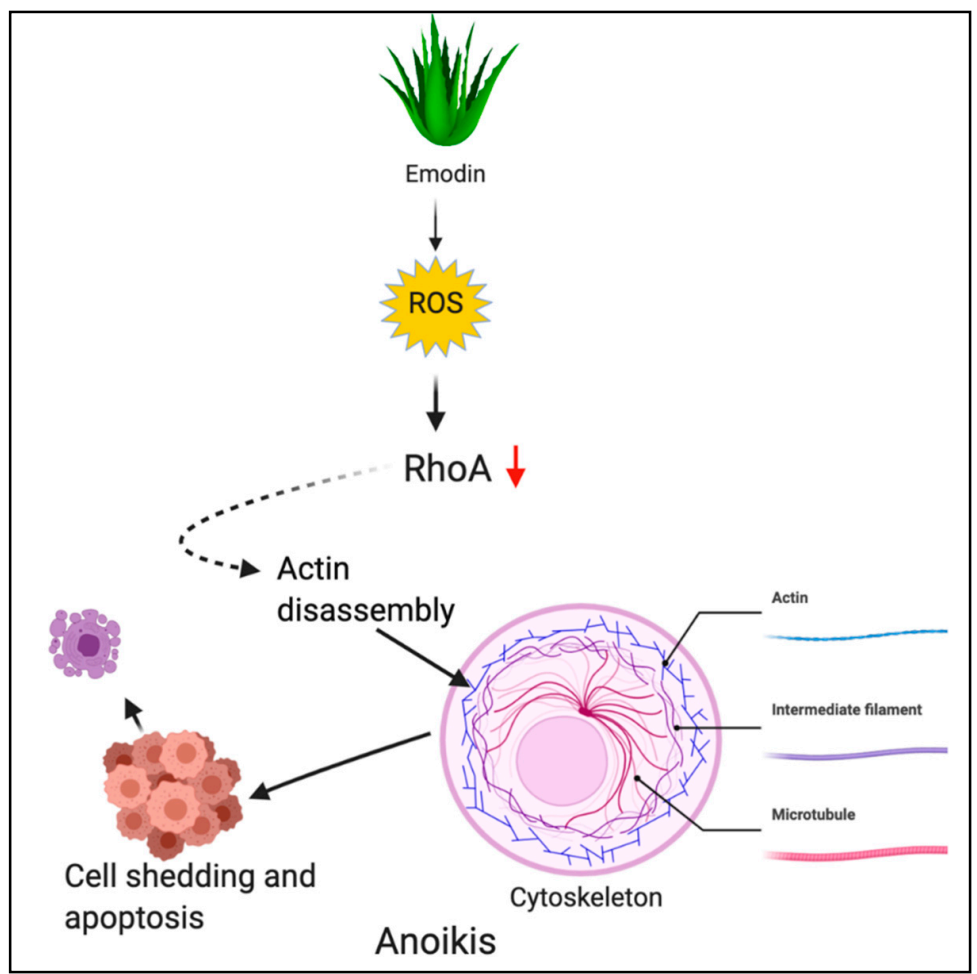

Figure 5. ROS-mediated anoikis by phytochemicals. Figure created with BioRender.com.

\section{Conclusions}

The ability of natural phytochemicals to modulate various signaling pathways make them promising therapeutic candidates in cancer. Many phytochemicals have progressed towards clinical trials against various malignancies such as breast, pancreatic, colon, and prostate cancers where promising results have been observed. Since cancer cells survive on levels of ROS that are slightly higher than normal cells, they are more sensitive to external perturbation. Fine-tuning of ROS levels using phytochemicals is a promising therapeutic strategy in cancer. Additionally, recent findings such as photooxidative stress using phytochemicals have provided selective targeting of cancer cells. However, there are a few challenges which need to be addressed in terms of the pharmacokinetic parameters of phytochemicals. In order to induce sufficient ROS levels for anti-cancer activity, specific plasma levels of the phytochemicals need to be attained. It has been observed that some of the phytochemicals do achieve the required plasma levels. A few such candidates having good pharmacokinetic parameters include BITC, PEITC, silibinin, and berberine. However, the majority of the phytochemicals fail to achieve required cytotoxic levels. This issue can be addressed by formulating the natural compound in advanced drug delivery systems such as nano drug delivery formulations. Various studies have been conducted in this aspect and nano drug delivery has proven to be an effective tool to achieve high plasma concentrations of the phytochemicals. Some of the successful candidates include sulforaphane and curcumin. A nano structured lipid formulation increased the bioavalability of sulforaphane in rat plasma while a nanoparticle formulation increased curcumin levels in human plasma by 10-15-fold. In the future, large cohort studies of ROS targeted phytochemicals are required, since these studies will provide data regarding efficacy, toxicity, bioavailability in clinical setup for their establishment as anti-cancer therapies in the market. An outline of pharmacokinetic data, selective action between normal and cancer cells by phytochemicals has been presented in Table 1. 
Table 1. Phytochemicals are associated with ROS-mediated programmed cell death in cancer.

\begin{tabular}{|c|c|c|c|c|c|c|c|c|}
\hline Sr. No. & Phytochemical & PCD Type & $\begin{array}{c}\text { Effective } \\
\text { Anti-Cancer } \\
\text { Concentration } \\
\text { (In Vitro) }\end{array}$ & $\begin{array}{l}\text { Dose } \\
\text { Administered } \\
\text { (In Vivo) }\end{array}$ & $\begin{array}{c}\text { Pharmacokinetic } \\
\text { Data }\end{array}$ & $\begin{array}{c}\text { TttCell } \\
\text { Lines/Subjects }\end{array}$ & Outcome/Comments & References \\
\hline 1 & Capsaicin & Apoptosis & $150 \mu \mathrm{M}$ & $2.5 \mathrm{mg} / \mathrm{kg}$ & Not stated & $\begin{array}{c}\text { Animal } \\
\text { subject-Mice } \\
\text { In vitro study } \\
\text { Pancreatic } \\
\text { cancer cells }\end{array}$ & $\begin{array}{l}\text { Apoptosis was observed in AsPC- } 1 \text { and } \\
\text { BXPC }_{3} \text { cell lines at } 150 \mu \mathrm{M} \text { concentration, } \\
\text { while no effect were observed in normal } \\
\text { (HPDE-6) cells. In an animal study, an oral } \\
\text { dose } 2.5 \mathrm{mg} / \mathrm{kg} \text { was effective in } \\
\text { suppressing tumor growth. Human } \\
\text { equivalent dose- } 0.202 \mathrm{mg} / \mathrm{kg} \text {. }\end{array}$ & {$[67,68]$} \\
\hline 2 & $\begin{array}{c}\text { Capsaicin } \\
\text { (Pharmacokinetic } \\
\text { study) }\end{array}$ & - & - & $5 \mathrm{~g}$ & $\begin{array}{c}C_{\max }: 2.47 \pm \\
0.13 \mathrm{ng} / \mathrm{mL}\end{array}$ & Human subjects & $\begin{array}{l}\text { The oral bioavailability of capsaicin is } \\
\text { effective for anti-diabetic effect, but plasma } \\
\text { level is less for its anti-cancer activity. }\end{array}$ & {$[123,124]$} \\
\hline 3 & Sulforaphane & Apoptosis & $5-10 \mu \mathrm{M}$ & - & - & - & $\begin{array}{l}\text { Various studies report anticancer activity } \\
\text { in a range of } 5-10 \mu \mathrm{M} \text { which is not } \\
\text { attainable through dietary intake. A study } \\
\text { in normal vs. cancerous prostate cells } \\
\text { revealed selective cytotoxicity of } \\
\text { sulforaphane in cancerous cells. No effect } \\
\text { was observed in normal cells at a dose } \\
\text { range of } 0-15 \mu \mathrm{M} \text {. }\end{array}$ & {$[125,126]$} \\
\hline 4 & $\begin{array}{l}\text { Sulforaphane } \\
\text { (Pharmacokinetic } \\
\text { study) }\end{array}$ & - & - & $30 \mathrm{mg} / \mathrm{kg}$ & $\begin{array}{l}C_{\max }: 772.8 \pm \\
54.36 \mathrm{ng} / \mathrm{mL}\end{array}$ & $\begin{array}{c}\text { Animal } \\
\text { subject-Rats }\end{array}$ & $\begin{array}{l}\text { Nano structured lipid formulation of } \\
\text { sulforaphane increased its bioavailability } \\
\text { in rat plasma wherein a dose close to } \\
\text { effective anticancer level was achieved. }\end{array}$ & [127] \\
\hline 5 & $\alpha$-lipoic acid & Apoptosis & $500 \mu \mathrm{M}$ & - & - & $\begin{array}{c}\text { In vitro study } \\
\text { hepatoma cell line }\end{array}$ & $\begin{array}{l}\text { ROS-mediated apoptosis was observed at } \\
500 \mu \mathrm{M} \text {. However, in another study, no } \\
\text { effect was observed in normal L02 liver } \\
\text { cells at } 5 \mathrm{mM} \text { concentration. }\end{array}$ & {$[72,128]$} \\
\hline
\end{tabular}


Table 1. Cont.

\begin{tabular}{|c|c|c|c|c|c|c|c|c|}
\hline Sr. No. & Phytochemical & PCD Type & $\begin{array}{c}\text { Effective } \\
\text { Anti-Cancer } \\
\text { Concentration } \\
\text { (In Vitro) }\end{array}$ & $\begin{array}{l}\text { Dose } \\
\text { Administered } \\
\text { (In Vivo) }\end{array}$ & $\begin{array}{c}\text { Pharmacokinetic } \\
\text { Data }\end{array}$ & $\begin{array}{c}\text { TttCell } \\
\text { Lines/Subjects }\end{array}$ & Outcome/Comments & References \\
\hline 7 & BITC & Apoptosis & - & - & - & $\begin{array}{l}\text { In vitro study } \\
\text { Pancreatic } \\
\text { cancer cells }\end{array}$ & $\begin{array}{l}\text { BITC caused ROS generation in a } \\
\text { concentration dependent manner starting } \\
\text { from } 2.5 \text { to } 20 \mu \mathrm{M} \text { in MIAPaCa- } 2 \text { and } \\
\text { Capan- } 2 \text { cell lines }\end{array}$ & {$[79,130]$} \\
\hline 8 & BITC & Apoptosis & $<2.5-5 \mu \mathrm{M}$ & - & - & $\begin{array}{l}\text { In vitro study } \\
\text { Breast cancer cells } \\
\text { and normal } \\
\text { mammary } \\
\text { epithelial cell line }\end{array}$ & $\begin{array}{l}\text { BITC induced ROS-mediated apoptosis in } \\
\text { MDA-MB- } 231 \text { and MCF-7 at IC } \mathrm{C}_{50} \text { value of } \\
<2.5 \mu \mathrm{m} \text { and } 5 \mu \mathrm{M} \text { respectively at } 24-\mathrm{h} \text { time } \\
\text { point. However, the } \mathrm{IC}_{50} \text { was } 20 \mu \mathrm{M} \text { in } \\
\text { normal mammary epithelial cell } \\
\text { line MCF-10A. }\end{array}$ & [131] \\
\hline 10 & $\begin{array}{c}\text { BITC } \\
\text { (Pharmacokinetic } \\
\text { study) }\end{array}$ & - & - & $12 \mu \mathrm{M} /$ day & $\begin{array}{c}\mathrm{C}_{\max }: \\
7.5 \mu \mathrm{M} \text { in tumor }\end{array}$ & $\begin{array}{c}\text { Animal } \\
\text { subject-Mice }\end{array}$ & $\begin{array}{c}\text { BXPC3 cells were subcutaneously } \\
\text { implanted and a } 43 \% \text { tumor inhibition was } \\
\text { observed with a concentration near } \text { IC }_{50} \\
\text { value achieved in plasma. }\end{array}$ & [74] \\
\hline 11 & PEITC & Apoptosis & $<5 \mu \mathrm{M}$ & - & - & $\begin{array}{l}\text { In vitro study } \\
\text { Breast cancer cells }\end{array}$ & $\begin{array}{l}\text { PEITC caused ROS-mediated apoptosis in } \\
\text { MDA-MB-231 and MCF-7 cell lines. }\end{array}$ & [86] \\
\hline
\end{tabular}


Table 1. Cont.

\begin{tabular}{|c|c|c|c|c|c|c|c|c|}
\hline Sr. No. & Phytochemical & PCD Type & $\begin{array}{c}\text { Effective } \\
\text { Anti-Cancer } \\
\text { Concentration } \\
\text { (In Vitro) }\end{array}$ & $\begin{array}{l}\text { Dose } \\
\text { Administered } \\
\text { (In Vivo) }\end{array}$ & $\begin{array}{c}\text { Pharmacokinetic } \\
\text { Data }\end{array}$ & $\begin{array}{c}\text { TttCell } \\
\text { Lines/Subjects }\end{array}$ & Outcome/Comments & References \\
\hline 12 & PEITC & Apoptosis & 5-10 $\mu \mathrm{M}$ & - & - & $\begin{array}{l}\text { In vitro study } \\
\text { normal ovarian } \\
\text { epithelial cell line }\end{array}$ & $\begin{array}{l}\text { Ovarian epithelial cell line T72 was } \\
\text { transfected to over express Ras oncogene } \\
\text { to form oncogenic T72Ras cell line. } \\
\text { Following PEITC treatment, the } \\
\text { transformed cells showed higher } \\
\text { sensitivity to ROS as compared to normal } \\
\text { cells. Thus, showing selective activity } \\
\text { of PEITC. }\end{array}$ & [133] \\
\hline 13 & $\begin{array}{c}\text { PEITC } \\
\text { (Pharmacokinetic } \\
\text { study) }\end{array}$ & - & - & $10-100 \mu \mathrm{mol} / \mathrm{kg}$ & $\begin{array}{c}C_{\max }: \\
9-42 \mu \mathrm{M}\end{array}$ & $\begin{array}{c}\text { Animal } \\
\text { subjects-Rats }\end{array}$ & $\begin{array}{l}\text { A considerably high level of PEITC was } \\
\text { achieved after oral administration of } \\
\text { PEITC than required for its } \\
\text { anti-cancer activity. }\end{array}$ & [134] \\
\hline 14 & Piperine & Apoptosis & $136-137 \mu \mathrm{M}$ & - & - & $\begin{array}{l}\text { In vitro study } \\
\text { Melanoma } \\
\text { cell lines }\end{array}$ & $\begin{array}{c}\text { Piperine induced RPS mediated apoptosis } \\
\text { in SKMEL-28 and B16-F0 cells at } 136 \mu \mathrm{M} \\
\text { and } 137 \mu \mathrm{M} \text { respectively at } 72-\mathrm{h} \\
\text { time point. }\end{array}$ & [90] \\
\hline 15 & Piperine & Apoptosis & $132 \mu \mathrm{g} / \mathrm{mL}$ & - & - & $\begin{array}{l}\text { In vitro study } \\
\text { Lung cancer cells } \\
\text { and normal } \\
\text { lung fibroblasts }\end{array}$ & $\begin{array}{l}\text { Piperine induced apoptotic cell death via } \\
\text { p53 dependent mitochondrial pathway in } \\
\text { A549 cancer cell line while no significant } \\
\text { cytotoxicity was observed in normal WI38 } \\
\text { human lung fibroblasts. ROS are } \\
\text { considered to be downstream effectors of } \\
\text { p53 mediated apoptosis. }\end{array}$ & {$[135,136]$} \\
\hline 16 & $\begin{array}{c}\text { Piperine } \\
\text { (Pharmacokinetic } \\
\text { study) }\end{array}$ & - & - & $\begin{array}{l}200 \mathrm{mg} \text { tablets } \\
\text { (Benjakul } \\
\text { formulation) }\end{array}$ & $\begin{array}{c}\mathrm{C}_{\max }: \\
1.078 \mu \mathrm{g} / \mathrm{mL}\end{array}$ & Human subjects & $\begin{array}{l}\text { Piperine is a major component of a } \\
\text { traditional Thai medication called } \\
\text { Benjakul. A dose of } 200 \mathrm{mg} \text { resulted in a } \\
\text { Cmax level of } 1.078 \mu \mathrm{g} / \mathrm{mL} \text { which is } \\
\text { significantly lower than that required for } \\
\text { anticancer effect. }\end{array}$ & [137] \\
\hline
\end{tabular}


Table 1. Cont.

\begin{tabular}{|c|c|c|c|c|c|c|c|c|}
\hline Sr. No. & Phytochemical & PCD Type & $\begin{array}{c}\text { Effective } \\
\text { Anti-Cancer } \\
\text { Concentration } \\
\text { (In Vitro) }\end{array}$ & $\begin{array}{c}\text { Dose } \\
\text { Administered } \\
\text { (In Vivo) }\end{array}$ & $\begin{array}{c}\text { Pharmacokinetic } \\
\text { Data }\end{array}$ & $\begin{array}{c}\text { TttCell } \\
\text { Lines/Subjects }\end{array}$ & Outcome/Comments & References \\
\hline 17 & Curcumin & Apoptosis & $25 \mu \mathrm{M}$ & $5 \mathrm{mg} / \mathrm{kg}$ & - & $\begin{array}{c}\text { In vitro study } \\
\text { Colorectal cancer } \\
\text { cells } \\
\text { Animal } \\
\text { subjects-Mice }\end{array}$ & $\begin{array}{l}\text { Curcumin induced ROS-mediated } \\
\text { apoptotic cell death in HCT-116 cell line at } \\
25 \mu \mathrm{M} \text { concentration within } 48 \mathrm{hh} \text {. } \\
\text { Curcumin showed considerable tumor } \\
\text { inhibition in in vivo xenograft model } \\
\text { following administration of } 5 \mathrm{mg} / \mathrm{kg} \\
\text { I.P dose. }\end{array}$ & [93] \\
\hline 18 & Curcumin & Apoptosis & $20 \mu \mathrm{M}$ & - & - & $\begin{array}{l}\text { In vitro study } \\
\text { Cervical cancer } \\
\text { cells and normal } \\
\text { cervical cells }\end{array}$ & $\begin{array}{c}\text { Curcumin induced ROS-mediated } \\
\text { apoptosis in cervical cancer cell lines } \\
\text { C33A, CaSki, HeLa, and ME180 cells at } \\
\text { approximately } 20 \mu \mathrm{M} \text { in } 48 \text {-h time period, } \\
\text { while it did not induce significant toxicity } \\
\text { in normal counterparts until } \\
\qquad 40 \mu \mathrm{M} \text { concentration. }\end{array}$ & [138] \\
\hline 20 & Withaferin A & Ferroptosis & $5-10 \mu \mathrm{M}$ & $4 \mathrm{mg} / \mathrm{kg}$ & Not stated & $\begin{array}{c}\text { In vitro study } \\
\text { Neuroblastoma } \\
\text { cell lines } \\
\text { Animal } \\
\text { subjects-Mice }\end{array}$ & $\begin{array}{l}\text { Crude Withaferin A and its nano particle } \\
\text { formulation for tumor targeting showed } \\
\text { ROS-mediated ferroptosis at } 10 \mu \mathrm{M} \text { in } \\
\text { neuroblastoma cell lines IMR-32, SK-N-SH, } \\
\text { Kelly, NB69, and CHP-134 within } 4-8 \mathrm{~h} \text {. } \\
\text { Tumor regression was mediated through } \\
\text { lipid peroxidation. }\end{array}$ & [95] \\
\hline
\end{tabular}


Table 1. Cont.

\begin{tabular}{|c|c|c|c|c|c|c|c|c|}
\hline Sr. No. & Phytochemical & PCD Type & $\begin{array}{c}\text { Effective } \\
\text { Anti-Cancer } \\
\text { Concentration } \\
\text { (In Vitro) }\end{array}$ & $\begin{array}{l}\text { Dose } \\
\text { Administered } \\
\text { (In Vivo) }\end{array}$ & $\begin{array}{c}\text { Pharmacokinetic } \\
\text { Data }\end{array}$ & $\begin{array}{c}\text { TttCell } \\
\text { Lines/Subjects }\end{array}$ & Outcome/Comments & References \\
\hline 21 & Withaferin A & Apoptotic & $1-50 \mu \mathrm{M}$ & $4 \mathrm{mg} / \mathrm{kg}$ & $\begin{array}{c}\mathrm{C}_{\max }: \\
1.8 \mu \mathrm{M}\end{array}$ & $\begin{array}{c}\text { In vitro study } \\
\text { Breast cancer cell } \\
\text { lines } \\
\text { Animal } \\
\text { subject-Mice }\end{array}$ & $\begin{array}{l}\text { Withaferin A displayed cytotoxicity in } \\
\text { breast carcinoma cell lines MDA-MB 231, } \\
\text { H1299, T47D, MCF-7, LN686, as well as } \\
\text { normal fibroblast cell line COS-7 in a wide } \\
\text { range of } 1-50 \mu \mathrm{M} \text { at } 72-\mathrm{h} \text { time point. The } \\
\text { IC }_{50} \text { was lesser than normal fibroblasts in } \\
\text { majority of the cancer cell lines. }\end{array}$ & [140] \\
\hline 22 & Bromelain & Ferroptosis & - & $3 \mathrm{mg} / \mathrm{kg}$ & Not stated & $\begin{array}{l}\text { In vitro study } \\
\text { Colon carcinoma } \\
\text { cell lines and } \\
\text { normal colon cell } \\
\text { line. } \\
\text { Animal } \\
\text { subjects-Mice }\end{array}$ & $\begin{array}{l}\text { Bromelain inhibited proliferation of in } \\
\text { Kras mutant colon cancer cell lines } \\
\text { HCT-116 and DLD-1 at } 50 \mu \mathrm{g} / \mathrm{mL} \text {, while it } \\
\text { induced significant ferroptosis in cancer } \\
\text { cell lines at a concentration of } 5 \mu \mathrm{m} \text { when } \\
\text { combined with Erastin as compared to } \\
\text { normal colon cells CCD1co. Bromelain } \\
\text { increased survival rate in treatment group } \\
\text { as compared to vehicle group. }\end{array}$ & [81] \\
\hline 23 & $\begin{array}{l}\text { Bromelain } \\
\text { (Pharmacokinetic } \\
\text { study) }\end{array}$ & - & - & $143 \mathrm{mg} / \mathrm{kg}$ & $\begin{array}{l}\mathrm{C}_{\max } \text { : Very low } \\
\text { (specific value } \\
\text { not stated) }\end{array}$ & Human subjects & $\begin{array}{c}\text { Bromelain showed very low }(\mathrm{ng} / \mathrm{mL}) \\
\text { plasma levels following oral } \\
\text { administration at } 143 \mathrm{mg} / \mathrm{kg} \text { body weight. }\end{array}$ & [141] \\
\hline 24 & Ruscogenin & Ferroptosis & 7.3-28.19 $\mu \mathrm{M}$ & 5 or $10 \mathrm{mg} / \mathrm{kg}$ & Not stated & $\begin{array}{c}\text { In vitro study } \\
\text { Pancreatic cancer } \\
\text { cells } \\
\text { Animal } \\
\text { subjects-Mice }\end{array}$ & $\begin{array}{l}\text { Ruscogenin induced significant ferroptotic } \\
\text { cell death in pancreatic cancer cell lines } \\
\text { BxPC-3, SW1990, PANC-1, and ASPC-1 } \\
\text { cells, as compared to normal pancreatic } \\
\text { cell line HPDE-6-C7 wherein not IC } 50 \text { was } \\
\text { detected at 72-h time point in HPDE6-C7 } \\
\text { cells. Additionally, it inhibited pancreatic } \\
\text { cancer growth in vivo. }\end{array}$ & [99] \\
\hline
\end{tabular}


Table 1. Cont.

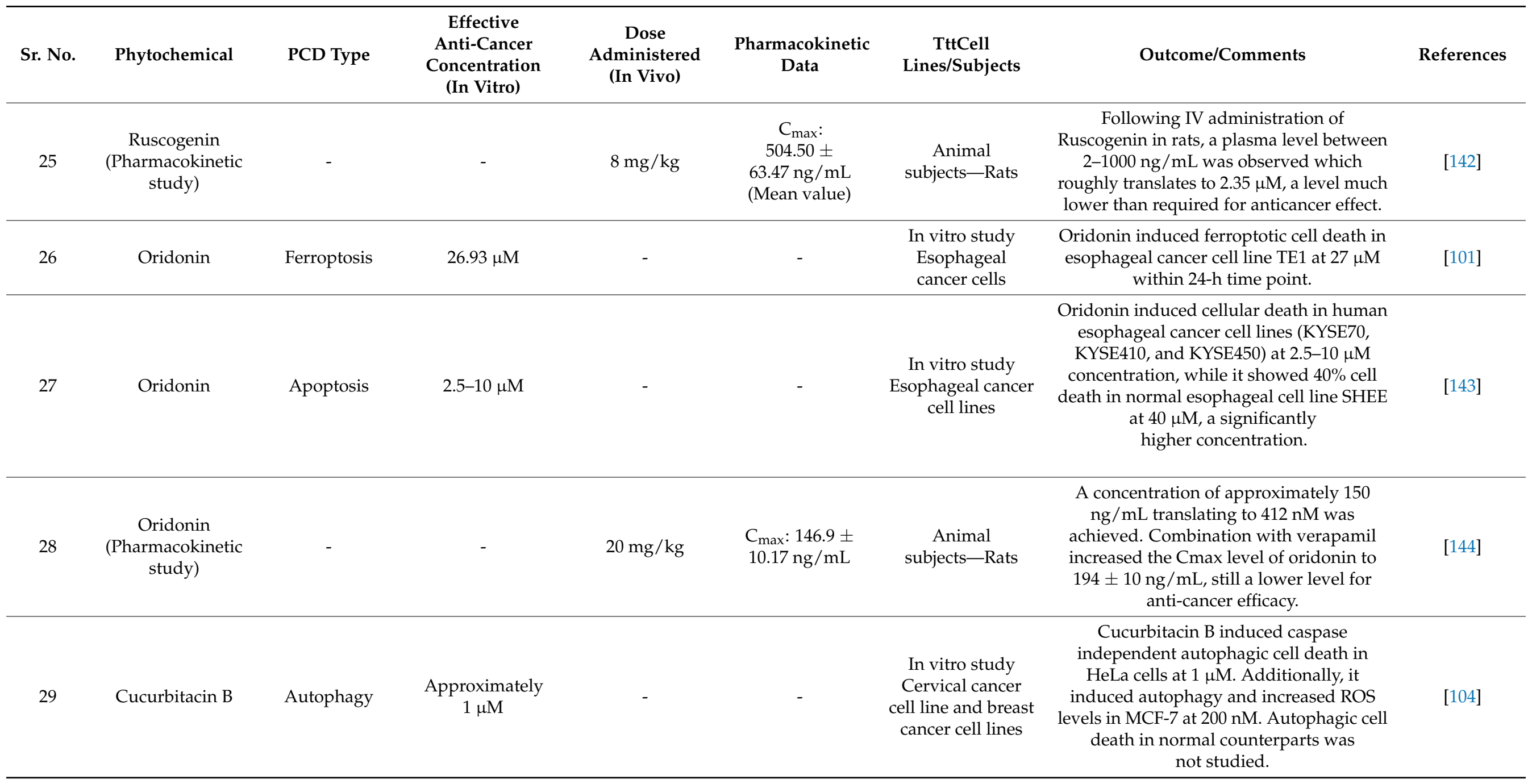


Table 1. Cont.

\begin{tabular}{|c|c|c|c|c|c|c|c|c|}
\hline Sr. No. & Phytochemical & PCD Type & $\begin{array}{c}\text { Effective } \\
\text { Anti-Cancer } \\
\text { Concentration } \\
\text { (In Vitro) }\end{array}$ & $\begin{array}{l}\text { Dose } \\
\text { Administered } \\
\text { (In Vivo) }\end{array}$ & $\begin{array}{c}\text { Pharmacokinetic } \\
\text { Data }\end{array}$ & $\begin{array}{c}\text { TttCell } \\
\text { Lines/Subjects }\end{array}$ & Outcome/Comments & References \\
\hline 31 & $\begin{array}{c}\text { Cucurbitacin B } \\
\text { (Pharmacokinetic } \\
\text { study) }\end{array}$ & - & - & $2-4 \mathrm{mg} / \mathrm{kg}$ & $\begin{array}{c}C_{\max }: \\
9-31 \mu \mathrm{g} / \mathrm{L}\end{array}$ & $\begin{array}{c}\text { Animal } \\
\text { subjects-Rats }\end{array}$ & $\begin{array}{c}\text { Following an oral administration of } 2-4 \\
\mathrm{mg} / \mathrm{kg} \text {, a significantly low plasma level } \\
\text { was achieved in rat plasma than required } \\
\text { for anti-cancer activity. }\end{array}$ & [146] \\
\hline 32 & Silibinin & Autophagy & $40 \mu \mathrm{M}$ & - & - & $\begin{array}{c}\text { In vitro study } \\
\text { Fibrosarcoma cells }\end{array}$ & $\begin{array}{c}\text { Silibinin induced autophagy in human } \\
\text { fibrosarcoma cell lines HT1080 at } 40 \mu \mathrm{M} \\
\text { within a period of } 4 \mathrm{~h} \text {. Cellular death was } \\
\text { concluded to be an autophagy mediated } \\
\text { apoptosis process. Effect on normal cells } \\
\text { was not studied. }\end{array}$ & [106] \\
\hline 33 & $\begin{array}{l}\text { Silibinin } \\
\text { (Pharmacokinetic } \\
\text { study) }\end{array}$ & - & - & $\begin{array}{c}360,720 \text { and } \\
1440 \mathrm{mg}\end{array}$ & $\begin{array}{c}\mathrm{C}_{\max }: \\
0.4,1.4 \text { and } 4 \pm \\
5.3 \mu \mathrm{M} \\
\text { respectively }\end{array}$ & $\begin{array}{l}\text { Human Subjects- } \\
\text { Colorectal cancer } \\
\text { patients }\end{array}$ & $\begin{array}{c}\text { Silibinin formulated capsules showed } \\
\text { considerably high levels required to exert } \\
\text { its anti-tumor effect. }\end{array}$ & [147] \\
\hline 34 & Allicin & $\begin{array}{l}\text { Autophagy } \\
\text { and apoptosis }\end{array}$ & $15-30 \mu \mathrm{g} / \mathrm{mL}$ & - & - & $\begin{array}{l}\text { In vitro study } \\
\text { Non-small cell } \\
\text { lung cancer } \\
\text { cell lines }\end{array}$ & $\begin{array}{l}\text { Allicin induced both autophagy and } \\
\text { apoptosis in human lung cancer cell lines } \\
\text { A549 and NCI-H460. }\end{array}$ & [109] \\
\hline 35 & Carnosol & Autophagy & $<25 \mu \mathrm{M}$ & - & - & $\begin{array}{l}\text { In vitro study } \\
\text { Breast cancer } \\
\text { cell lines }\end{array}$ & $\begin{array}{l}\text { Carnosol induced ROS-mediated } \\
\text { autophagy in triple negative breast cancer } \\
\text { cell line MDA-MB-231. Effect on normal } \\
\text { cell counterparts was not studied. }\end{array}$ & [113] \\
\hline
\end{tabular}


Table 1. Cont.

\begin{tabular}{|c|c|c|c|c|c|c|c|c|}
\hline Sr. No. & Phytochemical & PCD Type & $\begin{array}{c}\text { Effective } \\
\text { Anti-Cancer } \\
\text { Concentration } \\
\text { (In Vitro) }\end{array}$ & $\begin{array}{l}\text { Dose } \\
\text { Administered } \\
\text { (In Vivo) }\end{array}$ & $\begin{array}{l}\text { Pharmacokinetic } \\
\text { Data }\end{array}$ & $\begin{array}{c}\text { TttCell } \\
\text { Lines/Subjects }\end{array}$ & Outcome/Comments & References \\
\hline 36 & Quercetin & Autophagy & $200 \mu \mathrm{M}$ & $100 \mathrm{mg} / \mathrm{kg}$ & - & $\begin{array}{c}\text { In vitro study } \\
\text { Osteosarcoma cell } \\
\text { line } \\
\text { Animal } \\
\text { subjects-Mice }\end{array}$ & $\begin{array}{l}\text { Quercetin induced ROS-mediated } \\
\text { autophagic cell death in human } \\
\text { osteosarcoma cell line MG-63 and also } \\
\text { inhibited tumor growth in mice model. }\end{array}$ & [116] \\
\hline 38 & $\begin{array}{c}\text { Berberine } \\
\text { (Pharmacokinetic } \\
\text { study) }\end{array}$ & - & - & $200 \mathrm{mg} / \mathrm{kg}$ & $\begin{array}{c}\mathrm{C}_{\max }: \\
25.85 \pm \\
7.34 \mu \mathrm{g} / \mathrm{L}\end{array}$ & $\begin{array}{c}\text { Animal } \\
\text { subject-Rats }\end{array}$ & $\begin{array}{l}\text { A plasma level of } 25.85 \pm 7.34 \mu \mathrm{g} / \mathrm{L} \\
\text { equivalent to } 76 \mu \mathrm{M} \text { was achieved. }\end{array}$ & [148] \\
\hline 39 & Nobiletin & Pyroptosis & $34.85-35.31 \mu \mathrm{M}$ & - & - & $\begin{array}{l}\text { In vitro study } \\
\text { Ovarian cancer } \\
\text { cell lines }\end{array}$ & $\begin{array}{c}\text { Nobiletin induced cytotoxicity at } \\
\text { concentration of } 35 \mu \mathrm{M} \text { but no data } \\
\text { regarding its effect on normal cell lines } \\
\text { were shown. }\end{array}$ & [120] \\
\hline 40 & Nobiletin & Apoptosis & $40-80 \mu \mathrm{M}$ & $100 \mathrm{mg} / \mathrm{kg}$ & - & $\begin{array}{l}\text { In vitro study } \\
\text { Ovarian cancer } \\
\text { cell lines } \\
\text { OVCAR-3 and } \\
\text { A2780 } \\
\text { Animal } \\
\text { subject-Mice }\end{array}$ & $\begin{array}{c}\text { Nobiletin exhibited cytotoxicity in ovarian } \\
\text { cancer cell lines at } 40-80 \mu \mathrm{M} \text { while the } \\
\mathrm{IC}_{50} \text { for normal ovarian cell line was } \\
\text { around } 160 \mu \mathrm{M} \text {. } \\
\text { Additionally, significant tumor growth } \\
\text { inhibition was observed in athymic nude } \\
\text { mice model at a dose of } 100 \mathrm{mg} / \mathrm{kg} \text {. }\end{array}$ & [149] \\
\hline
\end{tabular}


Table 1. Cont.

\begin{tabular}{|c|c|c|c|c|c|c|c|c|}
\hline Sr. No. & Phytochemical & PCD Type & $\begin{array}{c}\text { Effective } \\
\text { Anti-Cancer } \\
\text { Concentration } \\
\text { (In Vitro) }\end{array}$ & $\begin{array}{l}\text { Dose } \\
\text { Administered } \\
\text { (In Vivo) }\end{array}$ & $\begin{array}{c}\text { Pharmacokinetic } \\
\text { Data }\end{array}$ & $\begin{array}{c}\text { TttCell } \\
\text { Lines/Subjects }\end{array}$ & Outcome/Comments & References \\
\hline 42 & Emodin & Anoikis & $10 \mu \mathrm{M}$ & - & - & $\begin{array}{l}\text { In vitro study } \\
\text { Gastric cancer } \\
\text { cell lines }\end{array}$ & $\begin{array}{l}\text { Significant difference observed in RhoA } \\
\text { expression between cancer and normal } \\
\text { cell lines. }\end{array}$ & [61] \\
\hline 43 & Emodin & Apoptosis & $70 \mu \mathrm{M}$ & - & - & $\begin{array}{l}\text { In vitro study } \\
\text { Cancer cell lines } \\
\text { isolated from } \\
\text { breast, lung, colon, } \\
\text { and cervix } \\
\text { carcinomas, } \\
\text { normal human } \\
\text { fibroblasts, and } \\
\text { normal human } \\
\text { keratinocytes }\end{array}$ & $\begin{array}{l}\text { No effect observed on normal cell lines } \\
\text { after 48-h treatment while cytotoxicity was } \\
\text { observed in cancer cell lines. }\end{array}$ & [151] \\
\hline 44 & $\begin{array}{l}\text { Emodin } \\
\text { (Pharmacokinetic } \\
\text { study) }\end{array}$ & - & - & $4.5 \mathrm{mg} / \mathrm{kg}$ & $\begin{array}{c}C_{\max }: 0.2 \pm \\
0.1 \mu \mathrm{M}\end{array}$ & $\begin{array}{c}\text { Animal } \\
\text { subject-Rats }\end{array}$ & $\begin{array}{l}\text { The concentration of free emodin achieved } \\
\text { in rat plasma after oral administration of } \\
\text { rhubarb extract was found to be much } \\
\text { lower than required for its } \\
\text { anti-cancer activity. }\end{array}$ & [152] \\
\hline
\end{tabular}


Author Contributions: Conception and design of the review, S.G.; writing-original and draft preparation, S.G.; editing, suggestions and supervision S.K.S. All authors have read and agreed to the published version of the manuscript.

Funding: Authors appreciate the financial support from Dodge Jones Foundation, Abilene, Texas.

Conflicts of Interest: The authors declare no conflict of interest.

\section{References}

1. Sies, H.; Jones, D.P. Reactive oxygen species (ROS) as pleiotropic physiological signalling agents. Nat. Rev. Mol. Cell. Biol. 2020, 21, 363-383. [CrossRef] [PubMed]

2. Pacher, P.; Beckman, J.S.; Liaudet, L. Nitric oxide and peroxynitrite in health and disease. Physiol. Rev. 2007, 87, 315-424. [CrossRef] [PubMed]

3. Patel, L.R.; Peng, J.; Chilian, W.M. Reactive Oxygen Species: The Good and the Bad. In Reactive Oxygen Species (ROS) in Living Cells; IntechOpen: London, UK, 2017. [CrossRef]

4. Milkovic, L.; Cipak Gasparovic, A.; Cindric, M.; Mouthuy, P.A.; Zarkovic, N. Short Overview of ROS as Cell Function Regulators and Their Implications in Therapy Concepts. Cells 2019, 8, 793. [CrossRef] [PubMed]

5. Winterbourn, C.C. Reconciling the chemistry and biology of reactive oxygen species. Nat. Chem. Biol. 2008, 4, 278-286. [CrossRef] [PubMed]

6. Schieber, M.; Chandel, N.S. ROS function in redox signaling and oxidative stress. Curr. Biol. 2014, 24, R453-R462. [CrossRef]

7. Miki, H.; Funato, Y. Regulation of intracellular signalling through cysteine oxidation by reactive oxygen species. J. Biochem. 2012, 151, 255-261. [CrossRef]

8. Droge, W. Free radicals in the physiological control of cell function. Physiol. Rev. 2002, 82, 47-95. [CrossRef]

9. Brieger, K.; Schiavone, S.; Miller, F.J., Jr.; Krause, K.H. Reactive oxygen species: From health to disease. Swiss Med. Wkly. 2012, 142, w13659. [CrossRef]

10. Oswald, M.C.W.; Garnham, N.; Sweeney, S.T.; Landgraf, M. Regulation of neuronal development and function by ROS. FEBS Lett. 2018, 592, 679-691. [CrossRef]

11. Wilson, C.; Gonzalez-Billault, C. Regulation of cytoskeletal dynamics by redox signaling and oxidative stress: Implications for neuronal development and trafficking. Front. Cell. Neurosci. 2015, 9, 381. [CrossRef]

12. Liu, Y.; Zhao, H.; Li, H.; Kalyanaraman, B.; Nicolosi, A.C.; Gutterman, D.D. Mitochondrial sources of $\mathrm{H}_{2} \mathrm{O}_{2}$ generation play a key role in flow-mediated dilation in human coronary resistance arteries. Circ. Res. 2003, 93, 573-580. [CrossRef] [PubMed]

13. Ushio-Fukai, M.; Alexander, R.W. Reactive oxygen species as mediators of angiogenesis signaling: Role of NAD(P)H oxidase. Mol. Cell. Biochem. 2004, 264, 85-97. [CrossRef] [PubMed]

14. Yun, J.; Rocic, P.; Pung, Y.F.; Belmadani, S.; Carrao, A.C.; Ohanyan, V.; Chilian, W.M. Redox-dependent mechanisms in coronary collateral growth: The "redox window" hypothesis. Antioxid. Redox Signal. 2009, 11, 1961-1974. [CrossRef] [PubMed]

15. Accardi, M.V.; Daniels, B.A.; Brown, P.M.; Fritschy, J.M.; Tyagarajan, S.K.; Bowie, D. Mitochondrial reactive oxygen species regulate the strength of inhibitory GABA-mediated synaptic transmission. Nat. Commun. 2014, 5, 3168. [CrossRef] [PubMed]

16. Fang, F.C. Antimicrobial actions of reactive oxygen species. mBio 2011, 2. [CrossRef] [PubMed]

17. Dupre-Crochet, S.; Erard, M.; Nubetae, O. ROS production in phagocytes: Why, when, and where? J. Leukoc. Biol. 2013, 94, 657-670. [CrossRef]

18. Kuiper, J.W.; Sun, C.; Magalhaes, M.A.; Glogauer, M. Rac regulates PtdInsP(3) signaling and the chemotactic compass through a redox-mediated feedback loop. Blood 2011, 118, 6164-6171. [CrossRef]

19. Tavassolifar, M.J.; Vodjgani, M.; Salehi, Z.; Izad, M. The Influence of Reactive Oxygen Species in the Immune System and Pathogenesis of Multiple Sclerosis. Autoimmune Dis. 2020, 2020, 5793817. [CrossRef]

20. Lee, K.; Esselman, W.J. cAMP potentiates $\mathrm{H}(2) \mathrm{O}(2)$-induced ERK1/2 phosphorylation without the requirement for MEK1/2 phosphorylation. Cell. Signal. 2001, 13, 645-652. [CrossRef]

21. Burton, G.J.; Jauniaux, E. Oxidative stress. Best Pr. Res. Clin. Obs. Gynaecol. 2011, 25, 287-299. [CrossRef]

22. Birben, E.; Sahiner, U.M.; Sackesen, C.; Erzurum, S.; Kalayci, O. Oxidative stress and antioxidant defense. World Allergy Organ. J. 2012, 5, 9-19. [CrossRef] [PubMed]

23. Zuo, L.; Zhou, T.; Pannell, B.K.; Ziegler, A.C.; Best, T.M. Biological and physiological role of reactive oxygen species-The good, the bad and the ugly. Acta Physiol. 2015, 214, 329-348. [CrossRef] [PubMed]

24. Leslie, N.R.; Bennett, D.; Lindsay, Y.E.; Stewart, H.; Gray, A.; Downes, C.P. Redox regulation of PI 3-kinase signalling via inactivation of PTEN. EMBO J. 2003, 22, 5501-5510. [CrossRef] [PubMed]

25. Okoh, V.O.; Felty, Q.; Parkash, J.; Poppiti, R.; Roy, D. Reactive oxygen species via redox signaling to PI3K/AKT pathway contribute to the malignant growth of 4-hydroxy estradiol-transformed mammary epithelial cells. PLoS ONE 2013, 8, e54206. [CrossRef]

26. Weinberg, F.; Hamanaka, R.; Wheaton, W.W.; Weinberg, S.; Joseph, J.; Lopez, M.; Kalyanaraman, B.; Mutlu, G.M.; Budinger, G.R.; Chandel, N.S. Mitochondrial metabolism and ROS generation are essential for Kras-mediated tumorigenicity. Proc. Natl. Acad. Sci. USA 2010, 107, 8788-8793. [CrossRef]

27. Gatenby, R.A.; Gillies, R.J. Why do cancers have high aerobic glycolysis? Nat. Rev. Cancer 2004, 4, 891-899. [CrossRef] 
28. Vafa, O.; Wade, M.; Kern, S.; Beeche, M.; Pandita, T.K.; Hampton, G.M.; Wahl, G.M. c-Myc can induce DNA damage, increase reactive oxygen species, and mitigate p53 function: A mechanism for oncogene-induced genetic instability. Mol. Cell 2002, 9, 1031-1044. [CrossRef]

29. Cat, B.; Stuhlmann, D.; Steinbrenner, H.; Alili, L.; Holtkotter, O.; Sies, H.; Brenneisen, P. Enhancement of tumor invasion depends on transdifferentiation of skin fibroblasts mediated by reactive oxygen species. J. Cell Sci. 2006, 119, 2727-2738. [CrossRef]

30. Kar, S.; Subbaram, S.; Carrico, P.M.; Melendez, J.A. Redox-control of matrix metalloproteinase-1: A critical link between free radicals, matrix remodeling and degenerative disease. Respir. Physiol. Neurobiol. 2010, 174, 299-306. [CrossRef]

31. Ozben, T. Oxidative stress and apoptosis: Impact on cancer therapy. J. Pharm. Sci. 2007, 96, 2181-2196. [CrossRef]

32. Kim, B.; Srivastava, S.K.; Kim, S.H. Caspase-9 as a therapeutic target for treating cancer. Expert Opin. Ther. Targets 2015, 19, 113-127. [CrossRef] [PubMed]

33. Madesh, M.; Hajnoczky, G. VDAC-dependent permeabilization of the outer mitochondrial membrane by superoxide induces rapid and massive cytochrome c release. J. Cell Biol. 2001, 155, 1003-1015. [CrossRef] [PubMed]

34. Circu, M.L.; Aw, T.Y. Reactive oxygen species, cellular redox systems, and apoptosis. Free Radic. Biol. Med. 2010, 48, 749-762 [CrossRef] [PubMed]

35. Ott, M.; Gogvadze, V.; Orrenius, S.; Zhivotovsky, B. Mitochondria, oxidative stress and cell death. Apoptosis 2007, 12, 913-922. [CrossRef] [PubMed]

36. Wang, J.; Yi, J. Cancer cell killing via ROS: To increase or decrease, that is the question. Cancer Biol. Ther. 2008, 7, 1875-1884 [CrossRef]

37. Kumar, R.; Herbert, P.E.; Warrens, A.N. An introduction to death receptors in apoptosis. Int. J. Surg. 2005, 3, 268-277. [CrossRef]

38. Safa, A.R.; Day, T.W.; Wu, C.H. Cellular FLICE-like inhibitory protein (C-FLIP): A novel target for cancer therapy. Curr. Cancer Drug Targets 2008, 8, 37-46. [CrossRef]

39. Wang, L.; Azad, N.; Kongkaneramit, L.; Chen, F.; Lu, Y.; Jiang, B.H.; Rojanasakul, Y. The Fas death signaling pathway connecting reactive oxygen species generation and FLICE inhibitory protein down-regulation. J. Immunol. 2008, 180, 3072-3080. [CrossRef]

40. He, C.; Klionsky, D.J. Regulation mechanisms and signaling pathways of autophagy. Annu. Rev. Genet. 2009, 43, 67-93. [CrossRef]

41. Xie, Z.; Klionsky, D.J. Autophagosome formation: Core machinery and adaptations. Nat. Cell. Biol 2007, 9, 1102-1109. [CrossRef]

42. Ranjan, A.; Kaushik, I.; Srivastava, S.K. Pimozide Suppresses the Growth of Brain Tumors by Targeting STAT3-Mediated Autophagy. Cells 2020, 9, 2141. [CrossRef] [PubMed]

43. Cordani, M.; Donadelli, M.; Strippoli, R.; Bazhin, A.V.; Sanchez-Alvarez, M. Interplay between ROS and Autophagy in Cancer and Aging: From Molecular Mechanisms to Novel Therapeutic Approaches. Oxid. Med. Cell. Longev. 2019, 2019, 8794612. [CrossRef] [PubMed]

44. Chen, Y.F.; Liu, H.; Luo, X.J.; Zhao, Z.; Zou, Z.Y.; Li, J.; Lin, X.J.; Liang, Y. The roles of reactive oxygen species (ROS) and autophagy in the survival and death of leukemia cells. Crit. Rev. Oncol. Hematol. 2017, 112, 21-30. [CrossRef] [PubMed]

45. Li, Y.; Corradetti, M.N.; Inoki, K.; Guan, K.L. TSC2: Filling the GAP in the mTOR signaling pathway. Trends Biochem. Sci. 2004, 29, 32-38. [CrossRef] [PubMed]

46. Alexander, A.; Kim, J.; Walker, C.L. ATM engages the TSC2/mTORC1 signaling node to regulate autophagy. Autophagy 2010, 6, 672-673. [CrossRef] [PubMed]

47. Dobrowolny, G.; Aucello, M.; Rizzuto, E.; Beccafico, S.; Mammucari, C.; Boncompagni, S.; Belia, S.; Wannenes, F.; Nicoletti, C.; Del Prete, Z.; et al. Skeletal muscle is a primary target of SOD1G93A-mediated toxicity. Cell Metab. 2008, 8, 425-436. [CrossRef]

48. Burton, T.R.; Gibson, S.B. The role of Bcl-2 family member BNIP3 in cell death and disease: NIPping at the heels of cell death. Cell Death Differ. 2009, 16, 515-523. [CrossRef]

49. White, E.; DiPaola, R.S. The double-edged sword of autophagy modulation in cancer. Clin. Cancer Res. 2009, 15, 5308-5316. [CrossRef]

50. Dixon, S.J.; Lemberg, K.M.; Lamprecht, M.R.; Skouta, R.; Zaitsev, E.M.; Gleason, C.E.; Patel, D.N.; Bauer, A.J.; Cantley, A.M.; Yang, W.S.; et al. Ferroptosis: An iron-dependent form of nonapoptotic cell death. Cell 2012, 149, 1060-1072. [CrossRef]

51. Li, J.; Cao, F.; Yin, H.L.; Huang, Z.J.; Lin, Z.T.; Mao, N.; Sun, B.; Wang, G. Ferroptosis: Past, present and future. Cell Death Dis. 2020, 11, 1-13. [CrossRef]

52. Ribas, V.; Garcia-Ruiz, C.; Fernandez-Checa, J.C. Glutathione and mitochondria. Front. Pharm. 2014, 5, 151. [CrossRef] [PubMed]

53. Yang, W.S.; SriRamaratnam, R.; Welsch, M.E.; Shimada, K.; Skouta, R.; Viswanathan, V.S.; Cheah, J.H.; Clemons, P.A.; Shamji, A.F.; Clish, C.B.; et al. Regulation of ferroptotic cancer cell death by GPX4. Cell 2014, 156, 317-331. [CrossRef] [PubMed]

54. Fang, Y.; Tian, S.; Pan, Y.; Li, W.; Wang, Q.; Tang, Y.; Yu, T.; Wu, X.; Shi, Y.; Ma, P.; et al. Pyroptosis: A new frontier in cancer. Biomed. Pharm. 2020, 121, 109595. [CrossRef] [PubMed]

55. Yang, Y.; Liu, P.Y.; Bao, W.; Chen, S.J.; Wu, F.S.; Zhu, P.Y. Hydrogen inhibits endometrial cancer growth via a ROS/NLRP3/caspase1/GSDMD-mediated pyroptotic pathway. BMC Cancer 2020, 20, 28. [CrossRef] [PubMed]

56. Gilmore, A.P. Anoikis. Cell Death Differ. 2005, 12 (Suppl. 2), 1473-1477. [CrossRef]

57. Fofaria, N.M.; Srivastava, S.K. Critical role of STAT3 in melanoma metastasis through anoikis resistance. Oncotarget 2014, 5, 7051-7064. [CrossRef]

58. Fofaria, N.M.; Srivastava, S.K. STAT3 induces anoikis resistance, promotes cell invasion and metastatic potential in pancreatic cancer cells. Carcinogenesis 2015, 36, 142-150. [CrossRef] 
59. Kandala, P.K.; Srivastava, S.K. Diindolylmethane-mediated Gli1 protein suppression induces anoikis in ovarian cancer cells in vitro and blocks tumor formation ability in vivo. J. Biol. Chem. 2012, 287, 28745-28754. [CrossRef]

60. Gupta, P.; Gupta, N.; Fofaria, N.M.; Ranjan, A.; Srivastava, S.K. HER2-mediated GLI2 stabilization promotes anoikis resistance and metastasis of breast cancer cells. Cancer Lett. 2019, 442, 68-81. [CrossRef]

61. Cai, J.; Niu, X.; Chen, Y.; Hu, Q.; Shi, G.; Wu, H.; Wang, J.; Yi, J. Emodin-induced generation of reactive oxygen species inhibits RhoA activation to sensitize gastric carcinoma cells to anoikis. Neoplasia 2008, 10, 41-51. [CrossRef]

62. Ranjan, A.; Ramachandran, S.; Gupta, N.; Kaushik, I.; Wright, S.; Srivastava, S.; Das, H.; Srivastava, S.; Prasad, S.; Srivastava, S.K. Role of Phytochemicals in Cancer Prevention. Int. J. Mol. Sci. 2019, 20, 4981. [CrossRef] [PubMed]

63. Boreddy, S.R.; Srivastava, S.K. Pancreatic cancer chemoprevention by phytochemicals. Cancer Lett. 2013, 334, 86-94. [CrossRef] [PubMed]

64. Cordell, G.A.; Araujo, O.E. Capsaicin: Identification, nomenclature, and pharmacotherapy. Ann. Pharm. 1993, 27, 330-336. [CrossRef] [PubMed]

65. Pramanik, K.C.; Fofaria, N.M.; Gupta, P.; Ranjan, A.; Kim, S.H.; Srivastava, S.K. Inhibition of beta-catenin signaling suppresses pancreatic tumor growth by disrupting nuclear beta-catenin/TCF-1 complex: Critical role of STAT-3. Oncotarget 2015, 6, 11561-11574. [CrossRef]

66. Pramanik, K.C.; Fofaria, N.M.; Gupta, P.; Srivastava, S.K. CBP-mediated FOXO-1 acetylation inhibits pancreatic tumor growth by targeting SirT. Mol. Cancer Ther. 2014, 13, 687-698. [CrossRef]

67. Pramanik, K.C.; Boreddy, S.R.; Srivastava, S.K. Role of mitochondrial electron transport chain complexes in capsaicin mediated oxidative stress leading to apoptosis in pancreatic cancer cells. PLoS ONE 2011, 6, e20151. [CrossRef]

68. Zhang, R.; Humphreys, I.; Sahu, R.P.; Shi, Y.; Srivastava, S.K. In vitro and in vivo induction of apoptosis by capsaicin in pancreatic cancer cells is mediated through ROS generation and mitochondrial death pathway. Apoptosis 2008, 13, 1465-1478. [CrossRef] [PubMed]

69. Houghton, C.A.; Fassett, R.G.; Coombes, J.S. Sulforaphane: Translational research from laboratory bench to clinic. Nutr. Rev. 2013, 71, 709-726. [CrossRef]

70. Singh, S.V.; Srivastava, S.K.; Choi, S.; Lew, K.L.; Antosiewicz, J.; Xiao, D.; Zeng, Y.; Watkins, S.C.; Johnson, C.S.; Trump, D.L.; et al. Sulforaphane-induced cell death in human prostate cancer cells is initiated by reactive oxygen species. J. Biol. Chem. 2005, 280, 19911-19924. [CrossRef]

71. Shay, K.P.; Moreau, R.F.; Smith, E.J.; Smith, A.R.; Hagen, T.M. Alpha-lipoic acid as a dietary supplement: Molecular mechanisms and therapeutic potential. Biochim. Biophys. Acta 2009, 1790, 1149-1160. [CrossRef]

72. Pibiri, M.; Sulas, P.; Camboni, T.; Leoni, V.P.; Simbula, G. alpha-Lipoic acid induces Endoplasmic Reticulum stress-mediated apoptosis in hepatoma cells. Sci. Rep. 2020, 10, 7139. [CrossRef] [PubMed]

73. Pramanik, K.C.; Srivastava, S.K.; Boreddy, S.R. Molecular Targets of Benzyl Isothiocyanates in Pancreatic Cancer; IntechOpen: London, UK, 2012.

74. Boreddy, S.R.; Pramanik, K.C.; Srivastava, S.K. Pancreatic tumor suppression by benzyl isothiocyanate is associated with inhibition of PI3K/AKT/FOXO pathway. Clin. Cancer Res. 2011, 17, 1784-1795. [CrossRef] [PubMed]

75. Boreddy, S.R.; Sahu, R.P.; Srivastava, S.K. Benzyl isothiocyanate suppresses pancreatic tumor angiogenesis and invasion by inhibiting HIF-alpha/VEGF/Rho-GTPases: Pivotal role of STAT-3. PLoS ONE 2011, 6, e25799. [CrossRef] [PubMed]

76. Batra, S.; Sahu, R.P.; Kandala, P.K.; Srivastava, S.K. Benzyl isothiocyanate-mediated inhibition of histone deacetylase leads to NF-kappaB turnoff in human pancreatic carcinoma cells. Mol. Cancer Ther. 2010, 9, 1596-1608. [CrossRef]

77. Sahu, R.P.; Epperly, M.W.; Srivastava, S.K. Benzyl isothiocyanate sensitizes human pancreatic cancer cells to radiation therapy. Front. Biosci. 2009, 1, 568-576. [CrossRef]

78. Wicker, C.A.; Sahu, R.P.; Kulkarni-Datar, K.; Srivastava, S.K.; Brown, T.L. BITC Sensitizes Pancreatic Adenocarcinomas to TRAIL-induced Apoptosis. Cancer Growth Metastasis 2010, 2009, 45-55. [CrossRef]

79. Sahu, R.P.; Zhang, R.; Batra, S.; Shi, Y.; Srivastava, S.K. Benzyl isothiocyanate-mediated generation of reactive oxygen species causes cell cycle arrest and induces apoptosis via activation of MAPK in human pancreatic cancer cells. Carcinogenesis 2009, 30, 1744-1753. [CrossRef]

80. Loganathan, S.; Kandala, P.K.; Gupta, P.; Srivastava, S.K. Inhibition of EGFR-AKT axis results in the suppression of ovarian tumors in vitro and in preclinical mouse model. PLoS ONE 2012, 7, e43577. [CrossRef]

81. Park, S.; Oh, J.; Kim, M.; Jin, E.J. Bromelain effectively suppresses Kras-mutant colorectal cancer by stimulating ferroptosis. Anim. Cells Syst. 2018, 22, 334-340. [CrossRef]

82. Gupta, P.; Wright, S.E.; Srivastava, S.K. PEITC treatment suppresses myeloid derived tumor suppressor cells to inhibit breast tumor growth. Oncoimmunology 2015, 4, e981449. [CrossRef]

83. Gupta, P.; Kim, B.; Kim, S.H.; Srivastava, S.K. Molecular targets of isothiocyanates in cancer: Recent advances. Mol. Nutr. Food Res. 2014, 58, 1685-1707. [CrossRef] [PubMed]

84. Gupta, P.; Wright, S.E.; Kim, S.H.; Srivastava, S.K. Phenethyl isothiocyanate: A comprehensive review of anti-cancer mechanisms. Biochim. Biophys. Acta 2014, 1846, 405-424. [CrossRef] [PubMed]

85. Gupta, P.; Adkins, C.; Lockman, P.; Srivastava, S.K. Metastasis of Breast Tumor Cells to Brain Is Suppressed by Phenethyl Isothiocyanate in a Novel In Vivo Metastasis Model. PLoS ONE 2013, 8, e67278. [CrossRef] [PubMed] 
86. Gupta, P.; Srivastava, S.K. Antitumor activity of phenethyl isothiocyanate in HER2-positive breast cancer models. BMC Med. 2012, 10, 80. [CrossRef]

87. Gorgani, L.; Mohammadi, M.; Najafpour, G.D.; Nikzad, M. Piperine-The Bioactive Compound of Black Pepper: From Isolation to Medicinal Formulations. Compr. Rev. Food Sci. Food 2017, 16, 124-140. [CrossRef] [PubMed]

88. Dhillon, H.; Chikara, S.; Reindl, K.M. Piperlongumine induces pancreatic cancer cell death by enhancing reactive oxygen species and DNA damage. Toxicol. Rep. 2014, 1, 309-318. [CrossRef] [PubMed]

89. Fofaria, N.M.; Qhattal, H.S.; Liu, X.; Srivastava, S.K. Nanoemulsion formulations for anti-cancer agent piplartineCharacterization, toxicological, pharmacokinetics and efficacy studies. Int. J. Pharm. 2016, 498, 12-22. [CrossRef]

90. Fofaria, N.M.; Kim, S.H.; Srivastava, S.K. Piperine causes G1 phase cell cycle arrest and apoptosis in melanoma cells through checkpoint kinase-1 activation. PLoS ONE 2014, 9, e94298. [CrossRef]

91. Hewlings, S.J.; Kalman, D.S. Curcumin: A Review of Its Effects on Human Health. Foods 2017, 6, 92. [CrossRef]

92. Sahu, R.P.; Batra, S.; Srivastava, S.K. Activation of ATM/Chk1 by curcumin causes cell cycle arrest and apoptosis in human pancreatic cancer cells. Br. J. Cancer 2009, 100, 1425-1433. [CrossRef]

93. Khaket, T.P.; Singh, M.P.; Khan, I.; Kang, S.C. In vitro and in vivo studies on potentiation of curcumin-induced lysosomaldependent apoptosis upon silencing of cathepsin C in colorectal cancer cells. Pharm. Res. 2020, 161, 105156. [CrossRef] [PubMed]

94. Vanden Berghe, W.; Sabbe, L.; Kaileh, M.; Haegeman, G.; Heyninck, K. Molecular insight in the multifunctional activities of Withaferin, A. Biochem. Pharm. 2012, 84, 1282-1291. [CrossRef] [PubMed]

95. Hassannia, B.; Wiernicki, B.; Ingold, I.; Qu, F.; Van Herck, S.; Tyurina, Y.Y.; Bayir, H.; Abhari, B.A.; Angeli, J.P.F.; Choi, S.M.; et al. Nano-targeted induction of dual ferroptotic mechanisms eradicates high-risk neuroblastoma. J. Clin. Investig. 2018, 128, 3341-3355. [CrossRef] [PubMed]

96. Pavan, R.; Jain, S.; Shraddha; Kumar, A. Properties and therapeutic application of bromelain: A review. Biotechnol. Res. Int. 2012, 2012, 976203. [CrossRef]

97. Doll, S.; Proneth, B.; Tyurina, Y.Y.; Panzilius, E.; Kobayashi, S.; Ingold, I.; Irmler, M.; Beckers, J.; Aichler, M.; Walch, A.; et al. ACSL4 dictates ferroptosis sensitivity by shaping cellular lipid composition. Nat. Chem. Biol. 2017, 13, 91-98. [CrossRef] [PubMed]

98. Masullo, M.; Pizza, C.; Piacente, S. Ruscus Genus: A Rich Source of Bioactive Steroidal Saponins. Planta Med. 2016, 82, 1513-1524. [CrossRef]

99. Song, Z.; Xiang, X.; Li, J.; Deng, J.; Fang, Z.; Zhang, L.; Xiong, J. Ruscogenin induces ferroptosis in pancreatic cancer cells. Oncol. Rep. 2020, 43, 516-524. [CrossRef]

100. Owona, B.A.; Schluesener, H.J. Molecular Insight in the Multifunctional Effects of Oridonin. Drugs R D 2015, 15, 233-244. [CrossRef]

101. Zhang, J.; Wang, N.; Zhou, Y.; Wang, K.; Sun, Y.; Yan, H.; Han, W.; Wang, X.; Wei, B.; Ke, Y.; et al. Oridonin induces ferroptosis by inhibiting gamma-glutamyl cycle in TE1 cells. Phytother. Res. 2020. [CrossRef]

102. Fujii, J.; Homma, T.; Kobayashi, S. Ferroptosis caused by cysteine insufficiency and oxidative insult. Free Radic. Res. 2019, 10, 1-12. [CrossRef]

103. Garg, S.; Kaul, S.C.; Wadhwa, R. Cucurbitacin B and cancer intervention: Chemistry, biology and mechanisms (Review). Int. J. Oncol. 2018, 52, 19-37. [CrossRef]

104. Zhang, T.; Li, Y.; Park, K.A.; Byun, H.S.; Won, M.; Jeon, J.; Lee, Y.; Seok, J.H.; Choi, S.W.; Lee, S.H.; et al. Cucurbitacin induces autophagy through mitochondrial ROS production which counteracts to limit caspase-dependent apoptosis. Autophagy 2012, 8 , 559-576. [CrossRef] [PubMed]

105. Ren, G.; Sha, T.; Guo, J.; Li, W.; Lu, J.; Chen, X. Cucurbitacin B induces DNA damage and autophagy mediated by reactive oxygen species (ROS) in MCF-7 breast cancer cells. J. Nat. Med. 2015, 69, 522-530. [CrossRef] [PubMed]

106. Duan, W.J.; Li, Q.S.; Xia, M.Y.; Tashiro, S.; Onodera, S.; Ikejima, T. Silibinin activated p53 and induced autophagic death in human fibrosarcoma HT1080 cells via reactive oxygen species-p38 and c-Jun N-terminal kinase pathways. Biol. Pharm. Bull. 2011, 34, 47-53. [CrossRef] [PubMed]

107. Jiang, K.; Wang, W.; Jin, X.; Wang, Z.; Ji, Z.; Meng, G. Silibinin, a natural flavonoid, induces autophagy via ROS-dependent mitochondrial dysfunction and loss of ATP involving BNIP3 in human MCF7 breast cancer cells. Oncol Rep 2015, 33, 2711-2718. [CrossRef] [PubMed]

108. Lawson, L.D.; Hunsaker, S.M. Allicin Bioavailability and Bioequivalence from Garlic Supplements and Garlic Foods. Nutrients 2018, 10, 812. [CrossRef]

109. Pandey, N.; Tyagi, G.; Kaur, P.; Pradhan, S.; Rajam, M.V.; Srivastava, T. Allicin Overcomes Hypoxia Mediated Cisplatin Resistance in Lung Cancer Cells through ROS Mediated Cell Death Pathway and by Suppressing Hypoxia Inducible Factors. Cell Physiol. Biochem. 2020, 54, 748-766. [CrossRef]

110. Chu, Y.L.; Ho, C.T.; Chung, J.G.; Raghu, R.; Lo, Y.C.; Sheen, L.Y. Allicin induces anti-human liver cancer cells through the p53 gene modulating apoptosis and autophagy. J. Agric. Food Chem. 2013, 61, 9839-9848. [CrossRef]

111. Johnson, J.J. Carnosol: A promising anti-cancer and anti-inflammatory agent. Cancer Lett. 2011, 305, 1-7. [CrossRef]

112. Choi, S.M.; Kim, D.H.; Chun, K.S. Carnosol induces apoptotic cell death through ROS-dependent inactivation of STAT3 in human melanoma G361 cells. Appl. Biol. Chem. 2019, 62, 1-11. [CrossRef] 
113. Al Dhaheri, Y.; Attoub, S.; Ramadan, G.; Arafat, K.; Bajbouj, K.; Karuvantevida, N.; AbuQamar, S.; Eid, A.; Iratni, R. Carnosol induces ROS-mediated beclin1-independent autophagy and apoptosis in triple negative breast cancer. PLoS ONE 2014, 9, e109630. [CrossRef]

114. Mlcek, J.; Jurikova, T.; Skrovankova, S.; Sochor, J. Quercetin and Its Anti-Allergic Immune Response. Molecules 2016, 21, 623. [CrossRef] [PubMed]

115. Hamidi, T.; Cano, C.E.; Grasso, D.; Garcia, M.N.; Sandi, M.J.; Calvo, E.L.; Dagorn, J.C.; Lomberk, G.; Urrutia, R.; Goruppi, S.; et al. Nupr1-aurora kinase A pathway provides protection against metabolic stress-mediated autophagic-associated cell death. Clin. Cancer Res. 2012, 18, 5234-5246. [CrossRef] [PubMed]

116. Wu, B.; Zeng, W.; Ouyang, W.; Xu, Q.; Chen, J.; Wang, B.; Zhang, X. Quercetin induced NUPR1-dependent autophagic cell death by disturbing reactive oxygen species homeostasis in osteosarcoma cells. J. Clin. Biochem. Nutr. 2020, 67, 137-145. [CrossRef] [PubMed]

117. Neag, M.A.; Mocan, A.; Echeverria, J.; Pop, R.M.; Bocsan, C.I.; Crisan, G.; Buzoianu, A.D. Berberine: Botanical Occurrence, Traditional Uses, Extraction Methods, and Relevance in Cardiovascular, Metabolic, Hepatic, and Renal Disorders. Front. Pharmacol. 2018, 9, 557. [CrossRef] [PubMed]

118. Lopes, T.Z.; de Moraes, F.R.; Tedesco, A.C.; Arni, R.K.; Rahal, P.; Calmon, M.F. Berberine associated photodynamic therapy promotes autophagy and apoptosis via ROS generation in renal carcinoma cells. Biomed. Pharmacother. 2020, $123,109794$. [CrossRef] [PubMed]

119. Huang, H.; Li, L.; Shi, W.; Liu, H.; Yang, J.; Yuan, X.; Wu, L. The Multifunctional Effects of Nobiletin and Its Metabolites In Vivo and In Vitro. Evid Based Complement. Altern. Med. 2016, 2016, 2918796. [CrossRef]

120. Zhang, R.; Chen, J.; Mao, L.; Guo, Y.; Hao, Y.; Deng, Y.; Han, X.; Li, Q.; Liao, W.; Yuan, M. Nobiletin Triggers Reactive Oxygen Species-Mediated Pyroptosis through Regulating Autophagy in Ovarian Cancer Cells. J. Agric. Food Chem. 2020, 68, 1326-1336. [CrossRef]

121. He, W.T.; Wan, H.; Hu, L.; Chen, P.; Wang, X.; Huang, Z.; Yang, Z.H.; Zhong, C.Q.; Han, J. Gasdermin D is an executor of pyroptosis and required for interleukin-1beta secretion. Cell Res. 2015, 25, 1285-1298. [CrossRef]

122. Huang, Q.; Lu, G.; Shen, H.M.; Chung, M.C.; Ong, C.N. Anti-cancer properties of anthraquinones from rhubarb. Med. Res. Rev. 2007, 27, 609-630. [CrossRef]

123. Suresh, D.; Srinivasan, K. Tissue distribution \& elimination of capsaicin, piperine \& curcumin following oral intake in rats. Indian J. Med. Res. 2010, 131, 682-691.

124. Chaiyasit, K.; Khovidhunkit, W.; Wittayalertpanya, S. Pharmacokinetic and the effect of capsaicin in Capsicum frutescens on decreasing plasma glucose level. J. Med. Assoc. Thail. 2009, 92, 108-113.

125. Sestili, P.; Fimognari, C. Cytotoxic and Antitumor Activity of Sulforaphane: The Role of Reactive Oxygen Species. Biomed. Res. Int. 2015, 2015, 402386. [CrossRef] [PubMed]

126. Clarke, J.D.; Hsu, A.; Yu, Z.; Dashwood, R.H.; Ho, E. Differential effects of sulforaphane on histone deacetylases, cell cycle arrest and apoptosis in normal prostate cells versus hyperplastic and cancerous prostate cells. Mol. Nutr. Food Res. 2011, 55, 999-1009. [CrossRef] [PubMed]

127. Soni, K.; Rizwanullah, M.; Kohli, K. Development and optimization of sulforaphane-loaded nanostructured lipid carriers by the Box-Behnken design for improved oral efficacy against cancer: In vitro, ex vivo and in vivo assessments. Artif. Cells Nanomed. Biotechnol. 2018, 46, 15-31. [CrossRef]

128. Shi, D.Y.; Liu, H.L.; Stern, J.S.; Yu, P.Z.; Liu, S.L. Alpha-lipoic acid induces apoptosis in hepatoma cells via the PTEN/Akt pathway. FEBS Lett 2008, 582, 1667-1671. [CrossRef]

129. Teichert, J.; Hermann, R.; Ruus, P.; Preiss, R. Plasma kinetics, metabolism, and urinary excretion of alpha-lipoic acid following oral administration in healthy volunteers. J. Clin. Pharmacol. 2003, 43, 1257-1267. [CrossRef]

130. Fofaria, N.M.; Ranjan, A.; Kim, S.H.; Srivastava, S.K. Mechanisms of the Anticancer Effects of Isothiocyanates. Enzymes 2015, 37, 111-137. [CrossRef]

131. Xiao, D.; Vogel, V.; Singh, S.V. Benzyl isothiocyanate-induced apoptosis in human breast cancer cells is initiated by reactive oxygen species and regulated by Bax and Bak. Mol. Cancer Ther. 2006, 5, 2931-2945. [CrossRef]

132. Srivastava, S.K.; Singh, S.V. Cell cycle arrest, apoptosis induction and inhibition of nuclear factor kappa B activation in antiproliferative activity of benzyl isothiocyanate against human pancreatic cancer cells. Carcinogenesis 2004, 25, 1701-1709. [CrossRef]

133. Trachootham, D.; Zhou, Y.; Zhang, H.; Demizu, Y.; Chen, Z.; Pelicano, H.; Chiao, P.J.; Achanta, G.; Arlinghaus, R.B.; Liu, J.; et al. Selective killing of oncogenically transformed cells through a ROS-mediated mechanism by beta-phenylethyl isothiocyanate. Cancer Cell 2006, 10, 241-252. [CrossRef]

134. Ji, Y.; Kuo, Y.; Morris, M.E. Pharmacokinetics of dietary phenethyl isothiocyanate in rats. Pharm. Res. 2005, 22, 1658-1666. [CrossRef] [PubMed]

135. Lin, Y.; Xu, J.; Liao, H.; Li, L.; Pan, L. Piperine induces apoptosis of lung cancer A549 cells via p53-dependent mitochondrial signaling pathway. Tumour Biol. 2014, 35, 3305-3310. [CrossRef] [PubMed]

136. Johnson, T.M.; Yu, Z.X.; Ferrans, V.J.; Lowenstein, R.A.; Finkel, T. Reactive oxygen species are downstream mediators of p53-dependent apoptosis. Proc. Natl. Acad. Sci. USA 1996, 93, 11848-11852. [CrossRef] [PubMed]

137. Jumpa-ngern, P. Pharmacokinetics of piperine following single dose administration of benjakul formulation in healthy Thai subjects. Afr. J. Pharm. Pharmacol. 2013, 7, 560-566. [CrossRef] 
138. Kim, B.; Kim, H.S.; Jung, E.J.; Lee, J.Y.; Tsang, B.K.; Lim, J.M.; Song, Y.S. Curcumin induces ER stress-mediated apoptosis through selective generation of reactive oxygen species in cervical cancer cells. Mol. Carcinog. 2016, 55, 918-928. [CrossRef]

139. Dei Cas, M.; Ghidoni, R. Dietary Curcumin: Correlation between Bioavailability and Health Potential. Nutrients 2019, 11, 2147. [CrossRef]

140. Thaiparambil, J.T.; Bender, L.; Ganesh, T.; Kline, E.; Patel, P.; Liu, Y.; Tighiouart, M.; Vertino, P.M.; Harvey, R.D.; Garcia, A.; et al. Withaferin A inhibits breast cancer invasion and metastasis at sub-cytotoxic doses by inducing vimentin disassembly and serine 56 phosphorylation. Int. J. Cancer 2011, 129, 2744-2755. [CrossRef]

141. Committee for Medicinal Products for Veterinary Use. European Public MRL Assessment Report (EPMAR) Bromelain; European Medicines Agency: Amsterdam, The Netherlands, 2017.

142. Ji, P.Y.; Li, Z.W.; Yang, Q.; Wu, R. Rapid determination of ruscogenin in rat plasma with application to pharmacokinetic study. J. Chromatogr. B 2015, 985, 71-74. [CrossRef]

143. Song, M.; Liu, X.; Liu, K.; Zhao, R.; Huang, H.; Shi, Y.; Zhang, M.; Zhou, S.; Xie, H.; Chen, H.; et al. Targeting AKT with Oridonin Inhibits Growth of Esophageal Squamous Cell Carcinoma In Vitro and Patient-Derived Xenografts In Vivo. Mol. Cancer Ther. 2018, 17, 1540-1553. [CrossRef]

144. Liu, J.; Zhang, N.; Li, N.; Fan, X.; Li, Y. Influence of verapamil on the pharmacokinetics of oridonin in rats. Pharm. Biol. 2019, 57, 787-791. [CrossRef]

145. Gao, Y.; Islam, M.S.; Tian, J.; Lui, V.W.; Xiao, D. Inactivation of ATP citrate lyase by Cucurbitacin B: A bioactive compound from cucumber, inhibits prostate cancer growth. Cancer Lett. 2014, 349, 15-25. [CrossRef] [PubMed]

146. Hunsakunachai, N.; Nuengchamnong, N.; Jiratchariyakul, W.; Kummalue, T.; Khemawoot, P. Pharmacokinetics of cucurbitacin B from Trichosanthes cucumerina L. in rats. BMC Complement. Altern. Med. 2019, 19, 157. [CrossRef] [PubMed]

147. Hoh, C.; Boocock, D.; Marczylo, T.; Singh, R.; Berry, D.P.; Dennison, A.R.; Hemingway, D.; Miller, A.; West, K.; Euden, S.; et al. Pilot study of oral silibinin, a putative chemopreventive agent, in colorectal cancer patients: Silibinin levels in plasma, colorectum, and liver and their pharmacodynamic consequences. Clin. Cancer Res. 2006, 12, 2944-2950. [CrossRef] [PubMed]

148. Tan, X.S.; Ma, J.Y.; Feng, R.; Ma, C.; Chen, W.J.; Sun, Y.P.; Fu, J.; Huang, M.; He, C.Y.; Shou, J.W.; et al. Tissue distribution of berberine and its metabolites after oral administration in rats. PLoS ONE 2013, 8, e77969. [CrossRef]

149. Chen, J.; Chen, A.Y.; Huang, H.; Ye, X.; Rollyson, W.D.; Perry, H.E.; Brown, K.C.; Rojanasakul, Y.; Rankin, G.O.; Dasgupta, P.; et al. The flavonoid nobiletin inhibits tumor growth and angiogenesis of ovarian cancers via the Akt pathway. Int. J. Oncol. 2015, 46, 2629-2638. [CrossRef]

150. Singh, S.P.; Wahajuddin; Tewari, D.; Patel, K.; Jain, G.K. Permeability determination and pharmacokinetic study of nobiletin in rat plasma and brain by validated high-performance liquid chromatography method. Fitoterapia 2011, 82, 1206-1214. [CrossRef]

151. Dumit, V.I.; Zerbes, R.M.; Kaeser-Pebernard, S.; Rackiewicz, M.; Wall, M.T.; Gretzmeier, C.; Kuttner, V.; van der Laan, M.; Braun, R.J.; Dengjel, J. Respiratory status determines the effect of emodin on cell viability. Oncotarget 2017, 8, 37478-37490. [CrossRef]

152. Wu, W.; Yan, R.; Yao, M.; Zhan, Y.; Wang, Y. Pharmacokinetics of anthraquinones in rat plasma after oral administration of a rhubarb extract. Biomed. Chromatogr. 2014, 28, 564-572. [CrossRef] 